\title{
U.S. Department of Energy FreedomCAR \& Vehicle Technologies Program Advanced Vehicle Testing Activity - Federal Fleet Use of Electric Vehicles - Technical Report
}

Mindy Kirkpatrick James Francfort

November 2003

Idaho National Engineering and Environmental Laboratory Bechtel BWXT Idaho, LLC 


\title{
U.S. Department of Energy FreedomCAR \& Vehicle Technologies Program Advanced Vehicle Testing Activity
}

\author{
Federal Fleet Use of Electric Vehicles
}

\author{
Mindy Kirkpatrick \\ James Francfort
}

November 2003

Idaho National Engineering and Environmental Laboratory Transportation Technology and Infrastructure Department Idaho Falls, Idaho 83415 


\section{Disclaimer}

This document highlights work sponsored by agencies of the U.S. Government. Neither the U.S. Government nor any agency thereof, nor any of their employees, makes any warranty, express or implied, or assumes any legal liability or responsibility for the accuracy, completeness, or usefulness of any information, apparatus, product, or process disclosed, or represents that its use would not infringe privately owned rights. Reference herein to any specific commercial product, process, or service by trade name, trademark, manufacturer, or otherwise does not necessarily constitute or imply its endorsement, recommendation, or favoring by the U.S. Government or any agency thereof. The views and opinions of authors expressed herein do not necessarily state or reflect those of the U.S. Government or any agency thereof. 


\section{ABSTRACT}

Per Executive Order 13031, "Federal Alternative Fueled Vehicle Leadership," the U.S. Department of Energy's (DOE's) Advanced Vehicle Testing Activity provided \$998,300 in incremental funding to support the deployment of 220 electric vehicles in 36 Federal fleets. The 145 electric Ford Ranger pickups and 75 electric Chrysler EPIC (Electric Powered Interurban Commuter) minivans were operated in 14 states and the District of Columbia. The 220 vehicles were driven an estimated average of 700,000 miles annually. The annual estimated use of the 220 electric vehicles contributed to 39,000 fewer gallons of petroleum being used by Federal fleets and the reduction in emissions of 1,450 pounds of smogforming pollution.

Numerous attempts were made to obtain information from all 36 fleets. Information responses were received from 25 fleets ( $69 \%$ response rate), as some Federal fleet personnel that were originally involved with the Incremental Funding Project were transferred, retired, or simply could not be found. In addition, many of the Department of Defense fleets indicated that they were supporting operations in Iraq and unable to provide information for the foreseeable future. It should be noted that the opinions of the 25 fleets is based on operating 179 of the 220 electric vehicles ( $81 \%$ response rate). The data from the 25 fleets is summarized in this report.

Twenty-two of the 25 fleets reported numerous problems with the vehicles, including mechanical, traction battery, and charging problems. Some of these problems, however, may have resulted from attempting to operate the vehicles beyond their capabilities. The majority of fleets reported that most of the vehicles were driven by numerous drivers each week, with most vehicles used for numerous trips per day. The vehicles were driven on average from 4 to 50 miles per day on a single charge. However, the majority of the fleets reported needing gasoline vehicles for missions beyond the capabilities of the electric vehicles, usually because of range limitations. Twelve fleets reported experiencing at least one charge depletion while driving, whereas nine fleets reported not having this problem.

Twenty-four of the 25 fleets responded that the electric vehicles were easy to use and 22 fleets indicated that the payload was adequate. Thirteen fleets reported charging problems; eleven fleets reported no charging problems. Nine fleets reported the vehicles broke down while driving; 14 fleets reported no onroad breakdowns. Some of the breakdowns while driving, however, appear to include normal flat tires and idiot lights coming on.

In spite of operation and charging problems, $59 \%$ of the fleets responded that they were satisfied, very satisfied, or extremely satisfied with the performance of the electric vehicles. As of September 2003, 74 of the electric vehicles were still being used and 107 had been returned to the manufacturers because the leases had concluded. 


\section{CONTENTS}

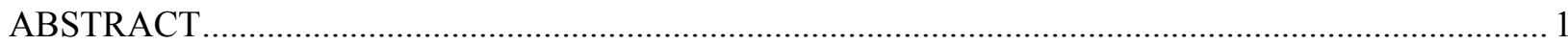

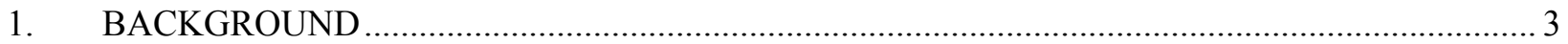

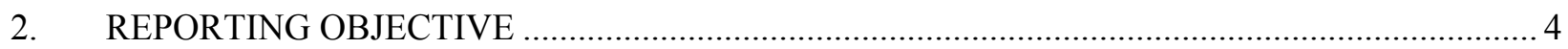

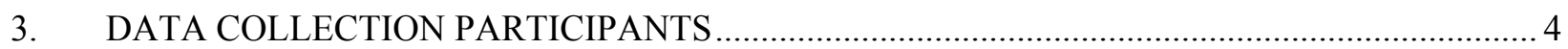

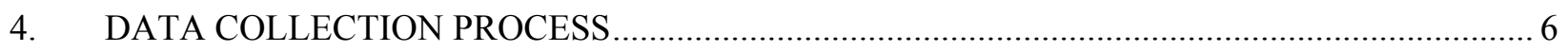

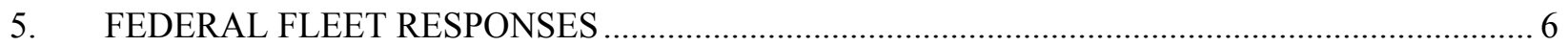

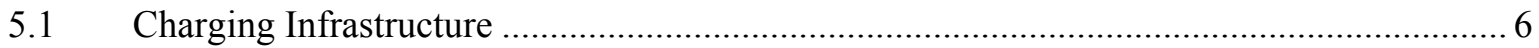

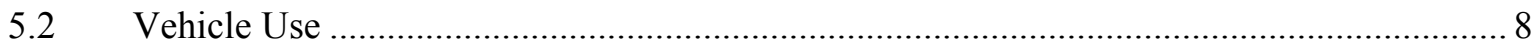

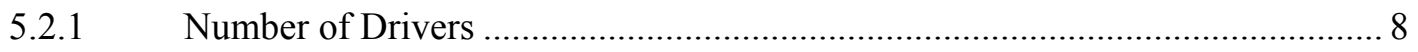

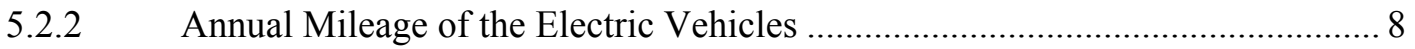

5.2.3 Average Daily Trips and Distances Traveled................................................ 10

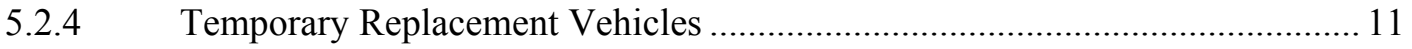

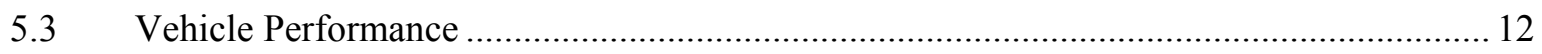

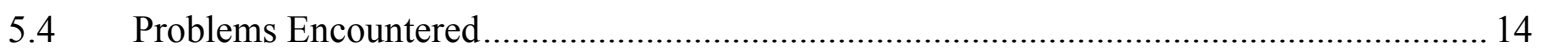

5.4.1 Mechanical Problems and Nonpropulsion Battery Problems........................... 14

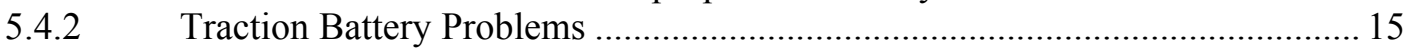

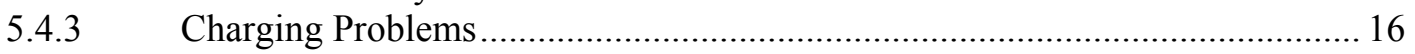

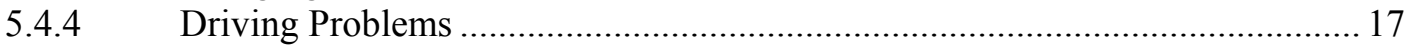

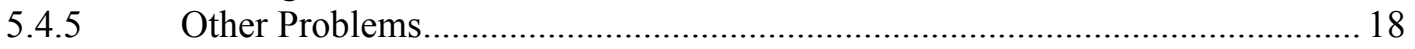

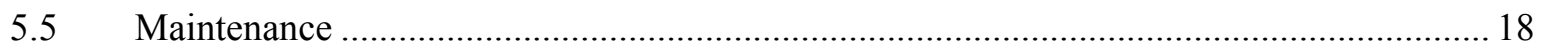

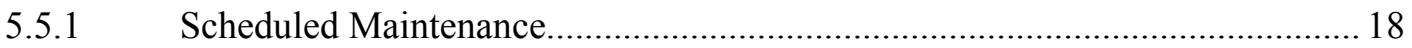

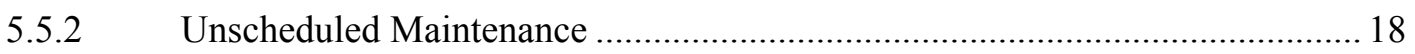

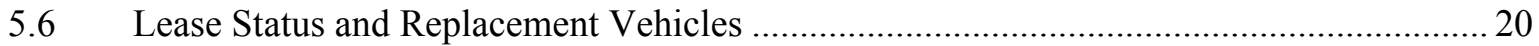

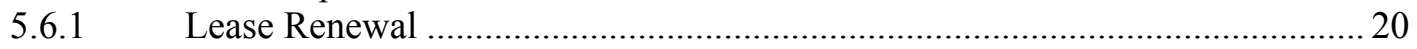

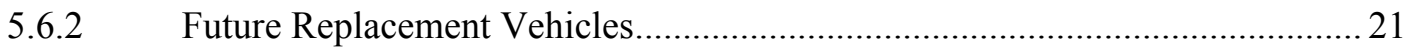

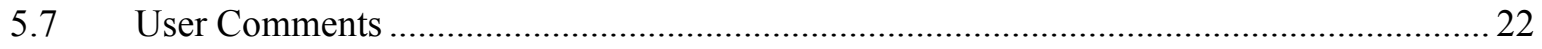

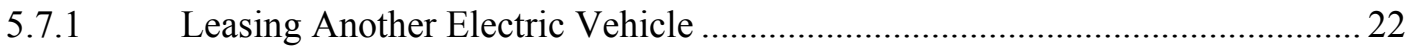

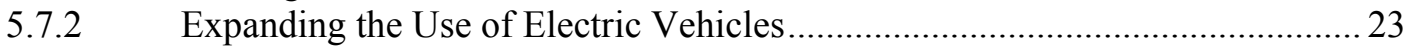

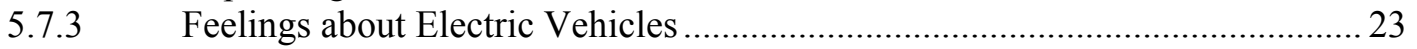

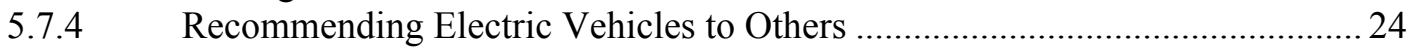

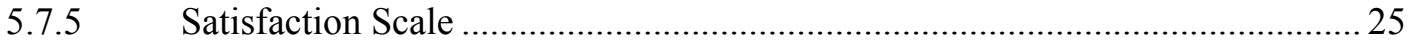

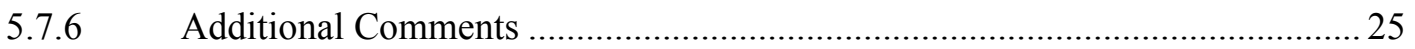

6. PETROLEUM DISPLACEMENT AND EMISSIONS REDUCTIONS ....................................26

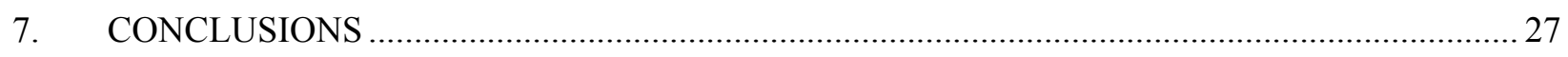

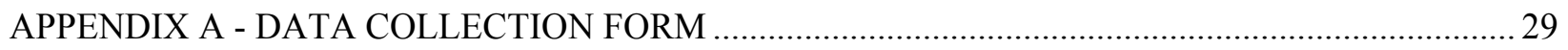




\section{BACKGROUND}

Section 6 of Executive Order 13031, "Federal Alternative Fueled Vehicle Leadership," mandated that the U.S. Department of Energy (DOE) provide Federal fleets with incremental funding to support the purchase or lease of electric vehicles. As a result, DOE's Advanced Vehicle Testing Activity provided $\$ 998,300$ in incremental funding to support the deployment of 220 electric vehicles in 36 Federal fleets (Figure 1). The funding was used to pay for half of the incremental cost for an electric vehicle (that is, the difference between the electric vehicle lease cost and the General Services Administration (GSA) lease cost for the gasoline vehicle equivalent), up to a total of $\$ 10,000$ per vehicle. The electric Ford Rangers and Chrysler EPICs (Electric Powered Interurban Commuter) were the only vehicle models leased as part of the Incremental Funding Project as they were the only electric vehicles available for leasing from vehicle manufacturers at the time.

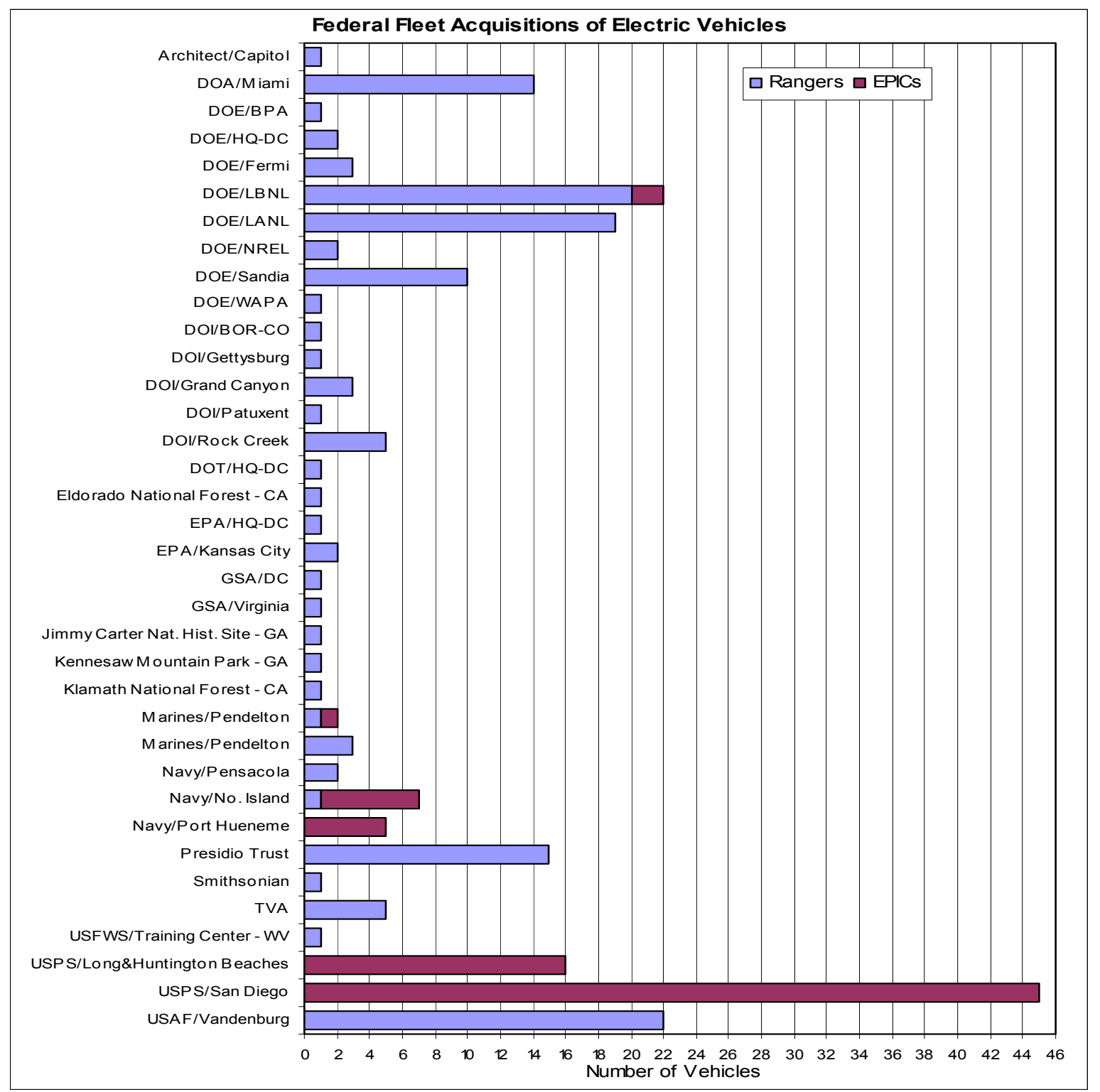

Figure 1. The 36 Federal fleets involved in the Incremental Funding Project and the type and number of electric vehicles leased. Table 1 gives the full names for each abbreviation. 
DOE made the incremental funding available to the Federal fleets either through the Idaho National Engineering and Environmental Laboratory (INEEL), which manages these activities for the Advanced Vehicle Testing Activity, or through GSA. This allowed the Federal fleets that normally leased gasoline vehicles through GSA to also lease the electric Rangers and EPICs from GSA (100 vehicles), with the DOE providing the incremental funding directly to GSA. GSA, however, discontinued this option as of the last quarter of calendar year 2000. For Federal fleets that preferred to lease electric vehicles directly from Ford or Chrysler, the INEEL provided the incremental funding directly to the fleets (120 vehicles). GSA did sign six pass-through leases between Ford and the Federal fleets during the first quarter of 2001, but the incremental funding was sent directly to the respective fleets by the INEEL. The six Ford Rangers are counted as part of the 120 vehicles receiving incremental funding through the INEEL.

During 1998, the U.S. Department of Agriculture in Miami, Florida, was the first of the 36 Federal fleets to take advantage of the incremental funding. The 35 remaining Federal fleets received incremental funding during calendar years 1999, 2000, and 2001. The 36 Federal fleets leased 145 electric Ford Ranger pickups and 75 electric Chrysler EPIC minivans. The 145 electric Rangers represent about 10\% of all the electric Rangers produced by Ford, and the 75 EPICs represent about $40 \%$ of all the electric EPICs leased by Chrysler in California, which was their primary leasing location.

The 36 Federal fleets are located in 14 states and the District of Columbia. The state with the most leased vehicles receiving incremental funding was California, where 139 vehicles were leased.

During 2003, the 36 Federal fleets that participated in the Incremental Funding Project were contacted and asked to respond to a series of questions. Of those 36 fleets, responses were received from 25 fleets. The data from the 25 fleets is summarized and presented in this report. For additional background information, see: Incremental Funding Activities - Final Report, INEEL/EXT-01-01355, October 2001.

Executive Order 13031 was superseded in April 2000 by Executive Order 13149, "Greening the Government through Federal Fleet and Transportation Efficiency." Executive Order 13149 does not provide for incremental funding; thus the funding activities reported herein have ended.

\section{REPORTING OBJECTIVE}

The objective of this data collection effort was to gather accurate information from the 36 Federal fleets regarding their experience obtaining and operating the 220 electric vehicles. The data collected covered multiple areas: the leasing process, charging infrastructure; and, vehicle use, performance, problems, and maintenance. The entire set of questions used is presented in Appendix A.

\section{DATA COLLECTION PARTICIPANTS}

Table 1 identifies the 36 Federal fleets involved in the Incremental Funding Project, the number and type(s) of vehicle(s) leased, and if the fleets participated in this data collection effort. 
Table 1: Federal fleets that participated in the Incremental Funding Project. $(\mathrm{P}=$ participated; NP $=$ did not participate; $\mathrm{NP}^{1}=$ While willing to provide a response, personnel changes made obtaining information impossible; this was considered a nonresponse)

\begin{tabular}{|c|c|c|c|}
\hline Participation & Federal Fleet Name & $\begin{array}{l}\text { Number of } \\
\text { Vehicles }\end{array}$ & $\begin{array}{l}\text { Vehicle } \\
\text { Model }\end{array}$ \\
\hline $\mathrm{P}$ & Architect of the Capitol & 1 & Ranger \\
\hline $\mathrm{P}$ & Department of Agriculture - Miami & 14 & Rangers \\
\hline $\mathrm{P}$ & $\begin{array}{l}\text { U.S. Department of Energy (DOE) - Bonneville Power } \\
\text { Administration }\end{array}$ & 1 & Ranger \\
\hline $\mathrm{P}$ & DOE - Headquarters, Office of Administrative Management & 2 & Rangers \\
\hline $\mathrm{P}$ & DOE/ Fermi Laboratories & 3 & Rangers \\
\hline \multirow[t]{2}{*}{$\mathrm{P}$} & \multirow{2}{*}{ DOE/ Lawrence Berkeley National Laboratory } & 20 & Rangers \\
\hline & & 2 & EPICs \\
\hline $\mathrm{P}$ & DOE/ Los Alamos National Laboratory & 19 & Rangers \\
\hline $\mathrm{P}$ & DOE/ National Renewable Energy Laboratory & 2 & Rangers \\
\hline $\mathrm{P}$ & DOE/ Sandia National Laboratory & 10 & Rangers \\
\hline $\mathrm{P}$ & DOE/ Western Area Power Administration & 1 & Ranger \\
\hline $\mathrm{P}$ & Department of Interior (DOI) - Bureau of Reclamation & 1 & Ranger \\
\hline $\mathrm{P}$ & DOI/ Gettysburg National Park & 1 & Ranger \\
\hline $\mathrm{P}$ & DOI/ Grand Canyon National Park & 3 & Rangers \\
\hline $\mathrm{P}$ & DOI/ USFWS, Paxtuent Research Refuge & 1 & Ranger \\
\hline $\mathrm{NP}^{1}$ & DOI/ NPS, Rock Creek Park & 5 & Rangers \\
\hline $\mathrm{P}$ & Department of Transportation - Headquarters & 1 & Ranger \\
\hline NP & Eldorado National Forest & 1 & Ranger \\
\hline NP & Environmental Protection Agency (EPA) - Headquarters & 1 & Ranger \\
\hline$* 1 / 2 \mathrm{P}$ & EPA/ Kansas City & 2 & Rangers \\
\hline NP & $\begin{array}{l}\text { General Services Administration (GSA) - DC. Public } \\
\text { Building Service }\end{array}$ & 1 & Ranger \\
\hline NP & GSA - Virginia, Crystal City & 1 & Ranger \\
\hline $\mathrm{P}$ & Jimmy Carter National Historic Site & 1 & Ranger \\
\hline $\mathrm{P}$ & Kennesaw Mountain National Battlefield Park & 1 & Ranger \\
\hline NP & Angeles National Forest & 1 & Ranger \\
\hline \multirow[t]{2}{*}{$\mathrm{P}$} & \multirow{2}{*}{ Marines, Camp Pendleton } & 1 & Ranger \\
\hline & & 1 & EPIC \\
\hline $\mathrm{P}$ & Marines, Camp Pendleton & 3 & Rangers \\
\hline $\mathrm{NP}^{1}$ & Navy, Pensacola & 2 & Rangers \\
\hline \multirow[t]{2}{*}{ NP } & \multirow{2}{*}{ Navy, North Island Station } & 1 & Ranger \\
\hline & & 6 & EPICs \\
\hline NP & Navy, Port Hueneme & 5 & EPICs \\
\hline NP & Presidio Trust & 15 & Rangers \\
\hline $\mathrm{P}$ & Smithsonian Institute & 1 & Ranger \\
\hline $\mathrm{P}$ & Tennessee Valley Administration & 5 & Rangers \\
\hline NP & $\begin{array}{l}\text { United States Fish and Wildlife Service (USFWS) National } \\
\text { Conservation Training Center }\end{array}$ & 1 & Ranger \\
\hline $\mathrm{P}$ & $\begin{array}{l}\text { United States Postal Service (USPS), Long Beach and } \\
\text { Huntington Beach }\end{array}$ & 16 & EPICs \\
\hline $\mathrm{P}$ & USPS, San Diego & 45 & EPICs \\
\hline $\mathrm{P}$ & USAF Vandenburg Air Force Base & 22 & Rangers \\
\hline
\end{tabular}




\section{DATA COLLECTION PROCESS}

All 36 Federal fleets were contacted by phone or e-mail and were asked to fill out a questionnaire about the electric vehicles they had leased through the Incremental Funding Project. Unfortunately, some of the original contacts at many of the fleets were no longer available due to retirements and reassignments. Also, several fleets indicated that they were extremely busy supporting military operations in Iraq, and they would not be able to participate. Of the 36 fleets, responses were received from 25 (69\% response rate), which covers 179 electric vehicles (115 Ford Rangers and 64 EPIC minivans).

Some fleets preferred to respond by e-mail, some by fax, and some preferred to respond by telephone. To maximize the response rate, the INEEL used the method preferred by the fleet. Many of the fleets were contacted numerous times by INEEL personnel in order to obtain the highest possible response rate (short of harassing the fleets).

\section{FEDERAL FLEET RESPONSES}

\subsection{Charging Infrastructure}

The Rangers and EPICs are equipped with onboard chargers. Their off-board infrastructure requirements consisted of intelligent connector stations and a connector (the plug). It appears that the connector infrastructure-to-vehicle ratio for the 220 vehicles was one-to-one. That is, one connector was installed for each vehicle. The responses received from 24 of the 25 fleets on using the charging plug were very positive. Only one negative response was received, stating that periodically the plug was difficult to connect (Figure 2).

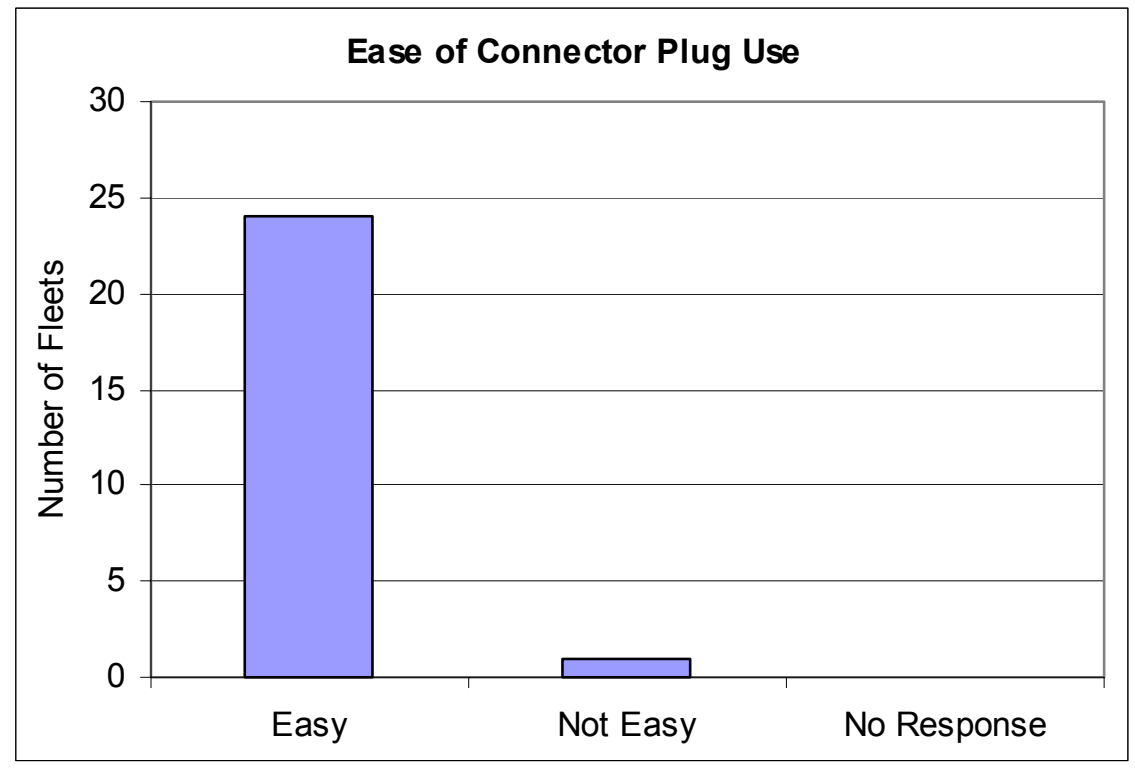

Figure 2: Ease of use for electric vehicle infrastructure plugs on a per fleet basis.

The fleets were asked how many days per week the electric vehicles were charged overnight. Of the 19 responses received, $63 \%$ said they charged their vehicles 7 days a week. The least number of days that the vehicles were charged was three (Figure 3). 


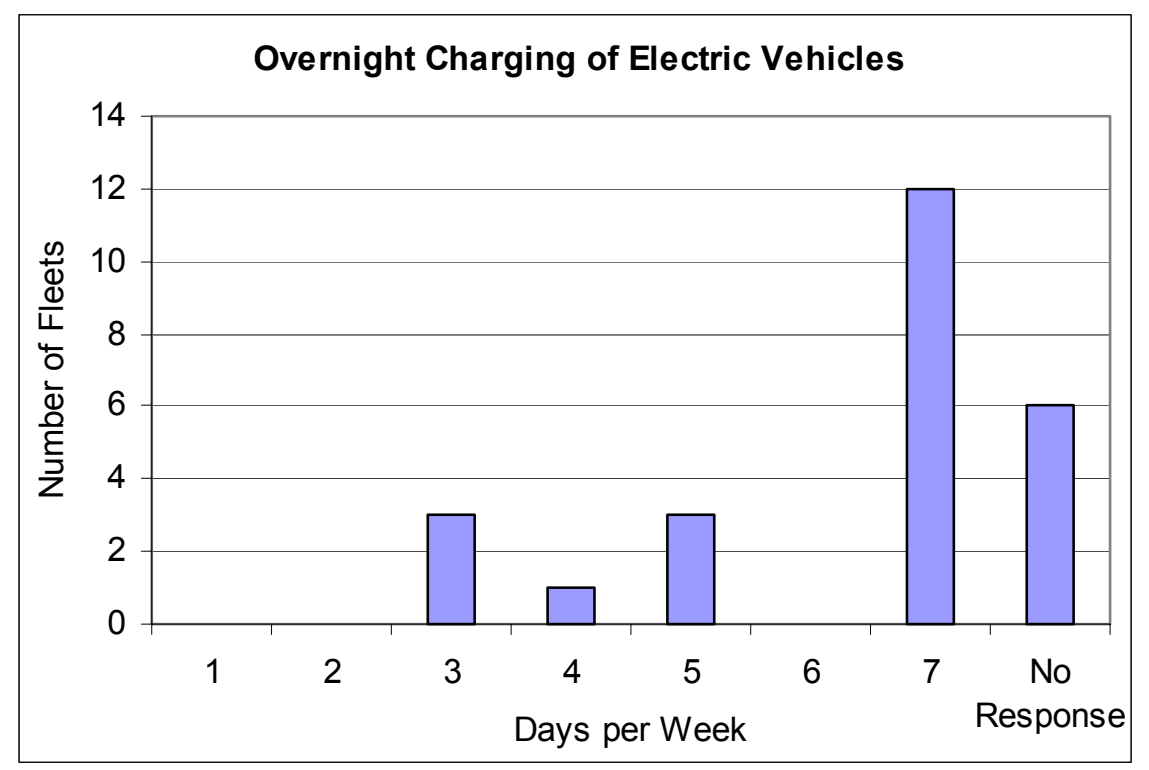

Figure 3. On a per fleet basis, days per week that the electric vehicles were charged overnight.

The fleets were asked how often they would charge the electric vehicles when the vehicles were parked at a charge connector during daytime use. Almost half of the 25 fleets always plugged their vehicles in when the vehicles were not in use (Figure 4). All fleets reported that the vehicles were plugged in sometime during the day.

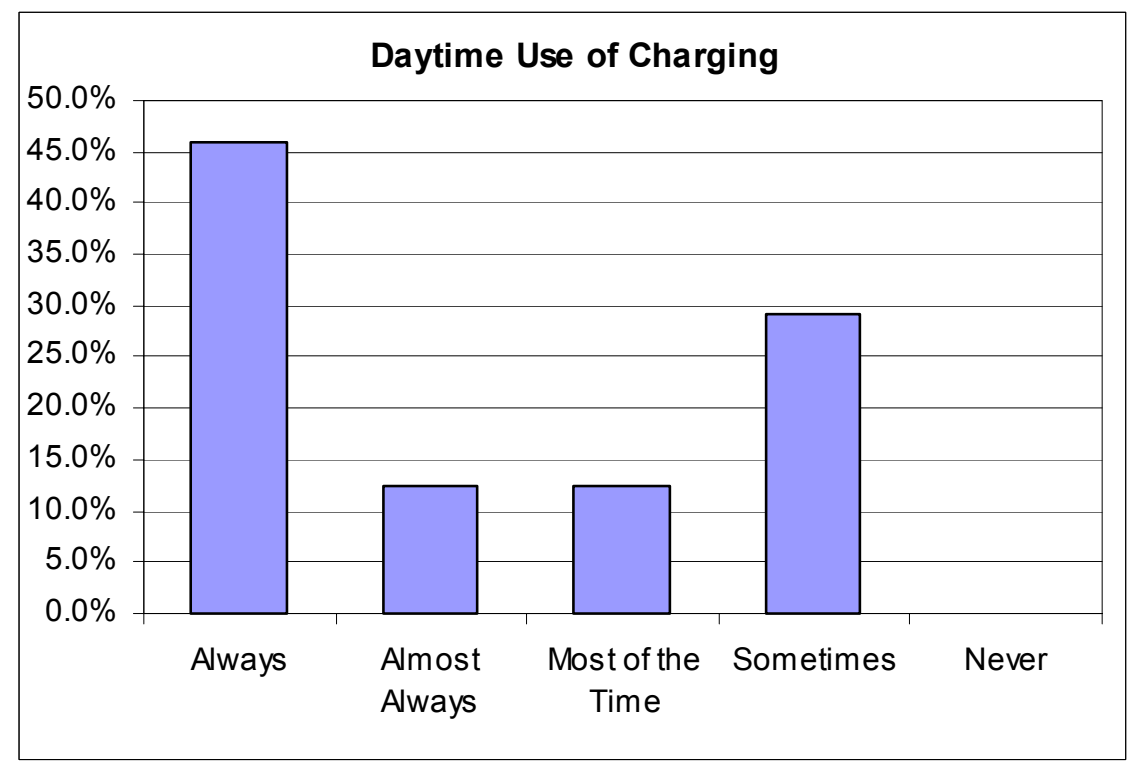

Figure 4. Fleet responses to the question regarding how often their electric vehicles were plugged in during daytime use (opportunity charging).

The fleets were also asked to describe any additional times they charged the vehicles. The following comments were received from six of the fleets.

- When it was cold, the vehicles would be charged during the day on one of the two charging stations located in the sunshine 
- When a vehicle is located at another vehicle's charger location, the operator took advantage of the opportunity to charge

- The vehicles were always plugged in when not in use to retain the highest state of charge possible, thus maximizing range for when needed

- The vehicle would be charged before anticipated continuous usage, long trips, and sometimes on weekends

- The $12-\mathrm{V}$ auxiliary battery required recharging by a portable unit quite often

- The vehicle would be charged whenever the battery power went to minimum.

\subsection{Vehicle Use}

\subsubsection{Number of Drivers}

Based on the responses received, multiple drivers were able to operate and obtain experience using the electric vehicles. Only two of the 25 fleets reported that their vehicles were only assigned to a single driver (Figure 5).

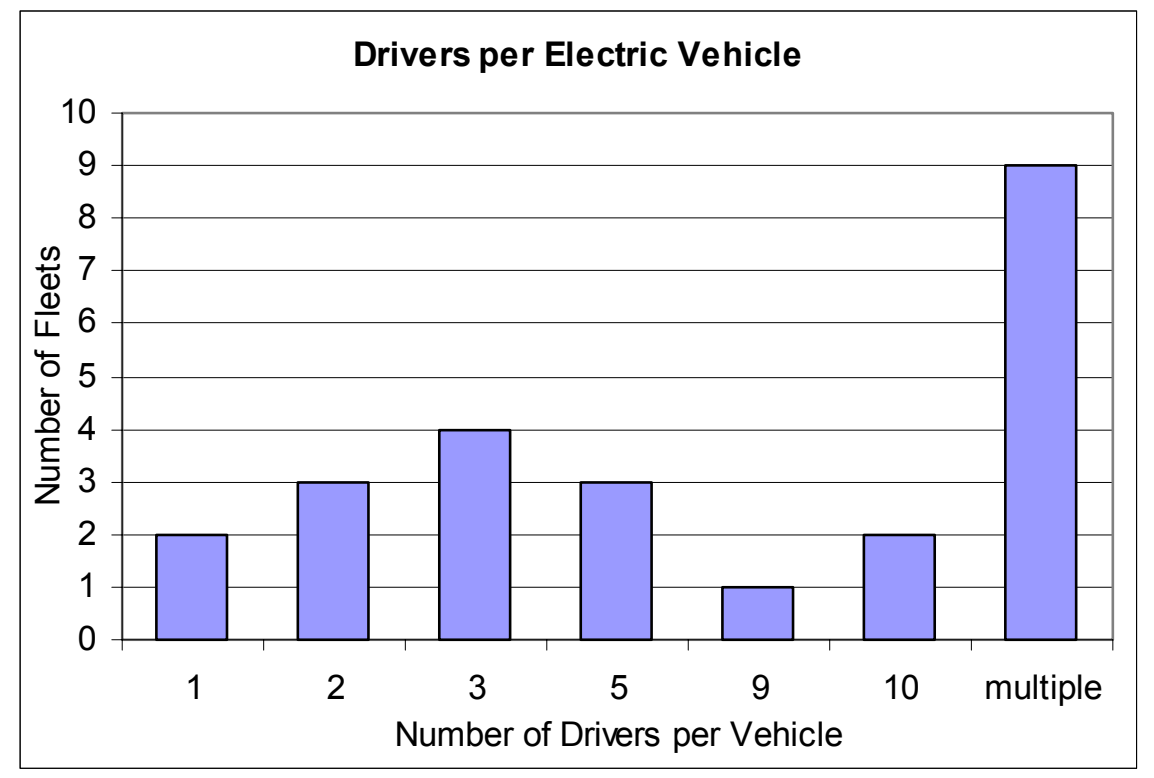

Figure 5. Average number of drivers using each electric vehicle, as reported by the fleets.

\subsubsection{Annual Mileage of the Electric Vehicles}

Twenty-four of the 25 fleets reported electric vehicle use for most of their vehicles in various formats, including: final odometer readings, total annual mileage per vehicle or per fleet, number of days used, and miles driven per day or per week. Since the miles driven for each vehicle was not collected or reported using a regimented data collection method, averages were calculated from the assorted data received from each fleet to estimate the number of miles that the electric vehicles were driven annually (Tables 2, 3, 4, and 5). Miles driven was calculated for both vehicle models. The electric Ford Rangers were driven annually an average of 3,156 miles per vehicle, for an extrapolated 145-vehicle total of 457,620 miles annually. The EPICs were driven annually an average of 3,239 miles per vehicle, for an extrapolated 75 -vehicle total of 242,925 miles annually. The entire fleet of 220 electric vehicles is estimated to have been driven 700,545 miles annually. (The average miles driven per vehicle for each model are well within the bounds of electric vehicle use that the authors have encountered previously). 
Table 2. Average miles that the 64 Ford Rangers returned to the manufacturer were driven.

\begin{tabular}{lrrrr}
\hline Agency & $\begin{array}{r}\text { Number of } \\
\text { Vehicles } \\
\text { Leased }\end{array}$ & $\begin{array}{r}\text { Weekly } \\
\text { Miles per } \\
\text { Vehicle }\end{array}$ & $\begin{array}{r}\text { Estimated } \\
\text { Annual Miles } \\
\text { per Vehicle }\end{array}$ & $\begin{array}{r}\text { Total Annual } \\
\text { Miles per Fleet }\end{array}$ \\
\hline Department of Agriculture - Miami & 14 & 35 & 1,820 & 25,480 \\
Office of the Architect of the Capitol & 1 & 100 & 5,200 & 5,200 \\
DOI - U.S. Bureau of Reclamation & 1 & 30 & 1,560 & 1,560 \\
DOE - Bonneville Power Administration & 1 & 17 & 884 & 884 \\
Department of Energy - Headquarters & 2 & 57 & 2,964 & 5,928 \\
DOI - National Park Service Gettysburg & 1 & 50 & 2,600 & 2,600 \\
Fish and Wildlife Service Paxtuent & 1 & 70 & 3,640 & 3,640 \\
U.S. Department of Transportation & 1 & 30 & 1,560 & 1,560 \\
U.S. Marine Corps - Cam Pendleton & 3 & 40 & 2,080 & 6,240 \\
DOE - Sandia & 10 & 30 & 1,560 & 15,600 \\
Smithsonian & 1 & 25 & 1,300 & 1,300 \\
Tennessee Valley Authority & 5 & 60 & 3,120 & 15,600 \\
DOE - LBNL & 20 & 45 & 2,340 & 46,800 \\
U.S. Marine Corps - Camp Pendleton & 1 & 30 & 1,560 & 1,560 \\
DOE - NREL & 2 & 50 & 2,600 & 5,200 \\
\hline$\quad$ Total & 64 & & & 139,152 \\
\hline
\end{tabular}

Table 3. Average miles that the 29 Ford Rangers not returned to the manufacturer were driven

\begin{tabular}{lrrrr}
\hline & $\begin{array}{r}\text { Number of } \\
\text { Vehicles } \\
\text { Leased }\end{array}$ & $\begin{array}{r}\text { Weekly } \\
\text { Miles per } \\
\text { Vehicle }\end{array}$ & $\begin{array}{r}\text { Estimated } \\
\text { Annual Mileage } \\
\text { per Vehicle }\end{array}$ & $\begin{array}{r}\text { Total Annual } \\
\text { Miles per Fleet }\end{array}$ \\
\hline DOI - National Park Service Grand Canyon & 1 & 97 & 5,041 & 5,041 \\
DOI - National Park Service Grand Canyon & 1 & 67 & 3,507 & 3,507 \\
DOI - National Park Service Grand Canyon & 1 & 48 & 2,491 & 2,491 \\
DOE - LANL & 19 & 170 & 5,500 & 104,500 \\
DOE - Fermi & 1 & 60 & 2,692 & 2,692 \\
DOE - Fermi & 1 & 31 & 1,590 & 1,590 \\
DOE - Fermi & 1 & 45 & 2,354 & 2,354 \\
EPA - Kansas City & 1 & 115 & 5,414 & 5,414 \\
DOE - Western Area Power Administration & 1 & 350 & 18,200 & 18,200 \\
National Park Service - Jimmy Carter & 1 & 49 & 2,555 & 2,555 \\
National Park Service - Kennesaw & 1 & 66 & 3,432 & 3,432 \\
\hline \multicolumn{1}{c}{ Total } & 29 & & & 154,330 \\
\hline
\end{tabular}

The 64 Ford Rangers already returned to the manufacturer (Table 2) were each driven a weighted average of 2,174 miles annually while the 29 Rangers not yet returned to the manufacturer (Table 3) were each driven a weighted average of 5,322 miles annually. The reason for the twice as high average annual mileage for the not yet returned Rangers is unknown. The annual average mileages for the EPICs returned (Table 4) and not returned (Table 5) only differed 200 miles (3,432 versus 3,232 miles). 
Table 4. Average miles that the EPIC Minivans returned to the manufacturer were driven.

\begin{tabular}{crrrr}
\hline Agency & $\begin{array}{r}\text { Number of } \\
\text { Vehicles Leased }\end{array}$ & $\begin{array}{r}\text { Weekly Miles } \\
\text { per Vehicle }\end{array}$ & $\begin{array}{r}\text { Estimated Annual } \\
\text { Mileage per Vehicle }\end{array}$ & $\begin{array}{r}\text { Total Annual } \\
\text { Miles per Fleet }\end{array}$ \\
\hline USPS - San Diego & 2 & 66 & 3,432 & 6,864 \\
\hline Total & 2 & & & 6,864 \\
\hline
\end{tabular}

Table 5. Average miles the EPIC Minivans not returned to the manufacturer were driven.

\begin{tabular}{lrrrr}
\hline Agency & $\begin{array}{r}\text { Number of } \\
\text { Vehicles Leased }\end{array}$ & $\begin{array}{r}\text { Weekly Miles } \\
\text { per Vehicle }\end{array}$ & $\begin{array}{r}\text { Estimated Annual } \\
\text { Mileage per Vehicle }\end{array}$ & $\begin{array}{r}\text { Total Annual } \\
\text { Miles per Fleet }\end{array}$ \\
\hline USPS - Long \& Hunt. Beach & 16 & 54 & 2,800 & 44,800 \\
Marine Corps - C. Pendleton & 1 & 30 & 1,560 & 1,560 \\
USPS - San Diego & 43 & 66 & 3,432 & 147,576 \\
\hline Total & 60 & & & 193,936 \\
\hline
\end{tabular}

\subsubsection{Average Daily Trips and Distances Traveled}

According to 22 of the fleets, the average number of trips made in each vehicle varied from 1 to 8 trips per day (Figure 6). Note that the U.S. Postal service provided the "City Driving" category.

Based on the data provided for 84 vehicles (68 Rangers and 16 EPICs), almost half of the electric vehicles were driven 6 to 10 miles per charge (Figure 7). The EPICs were driven from 5 to 15 miles and the Rangers from 4 to 50 miles per charge.

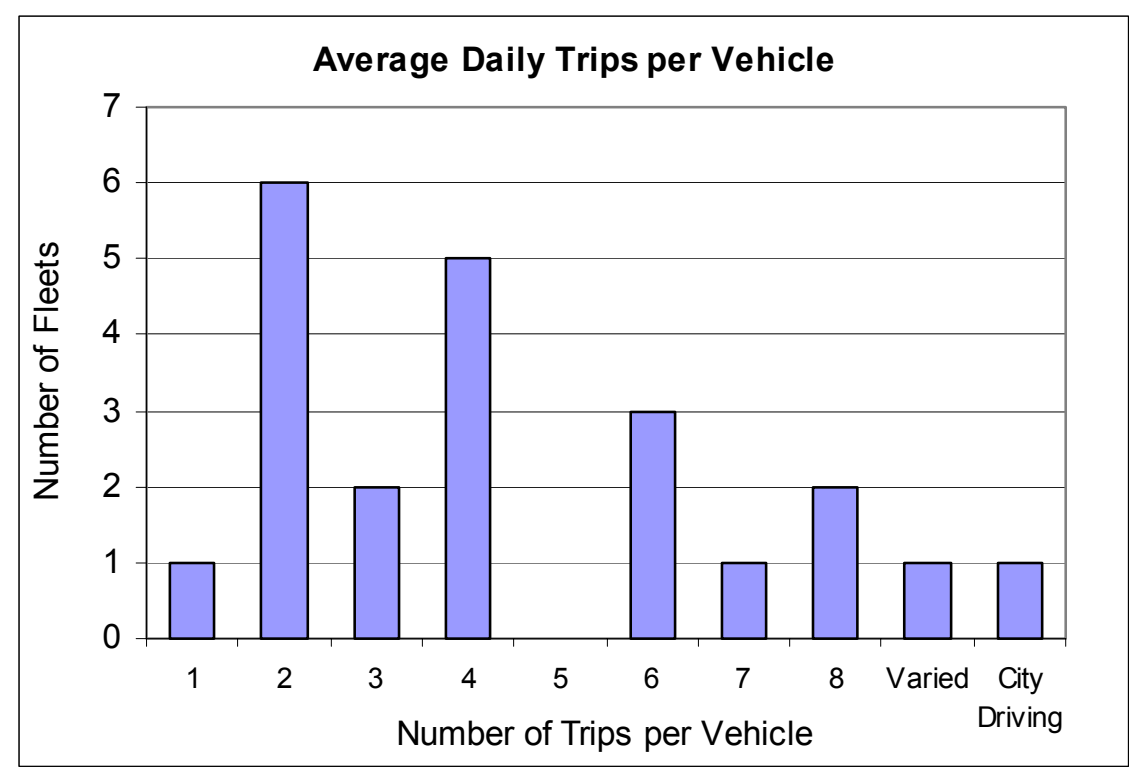

Figure 6. Average number of trips made per vehicle, as reported by 22 fleets. 


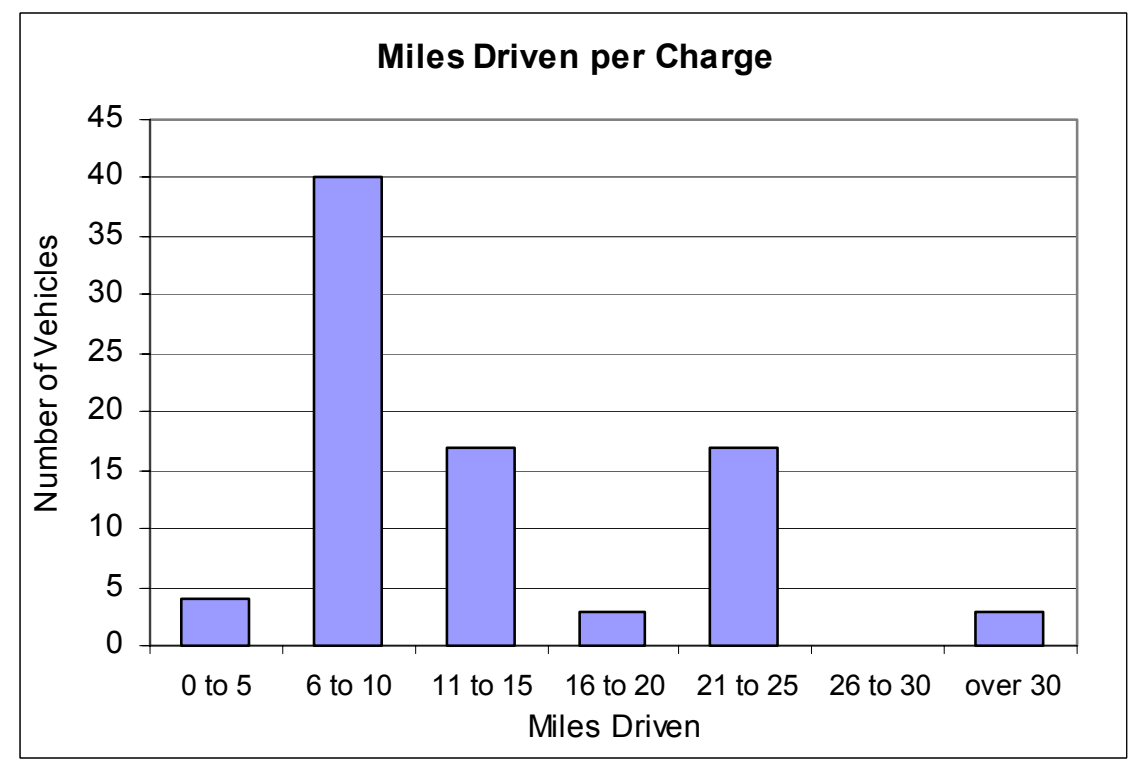

Figure 7. Average distance each vehicle was reported driven per charge, for the 84 vehicles for which distances were reported.

\subsubsection{Temporary Replacement Vehicles}

Twenty of 24 fleets reported sometimes using nonelectric vehicles in place of electric vehicles due to the limited range of the electric vehicles (Figure 8).

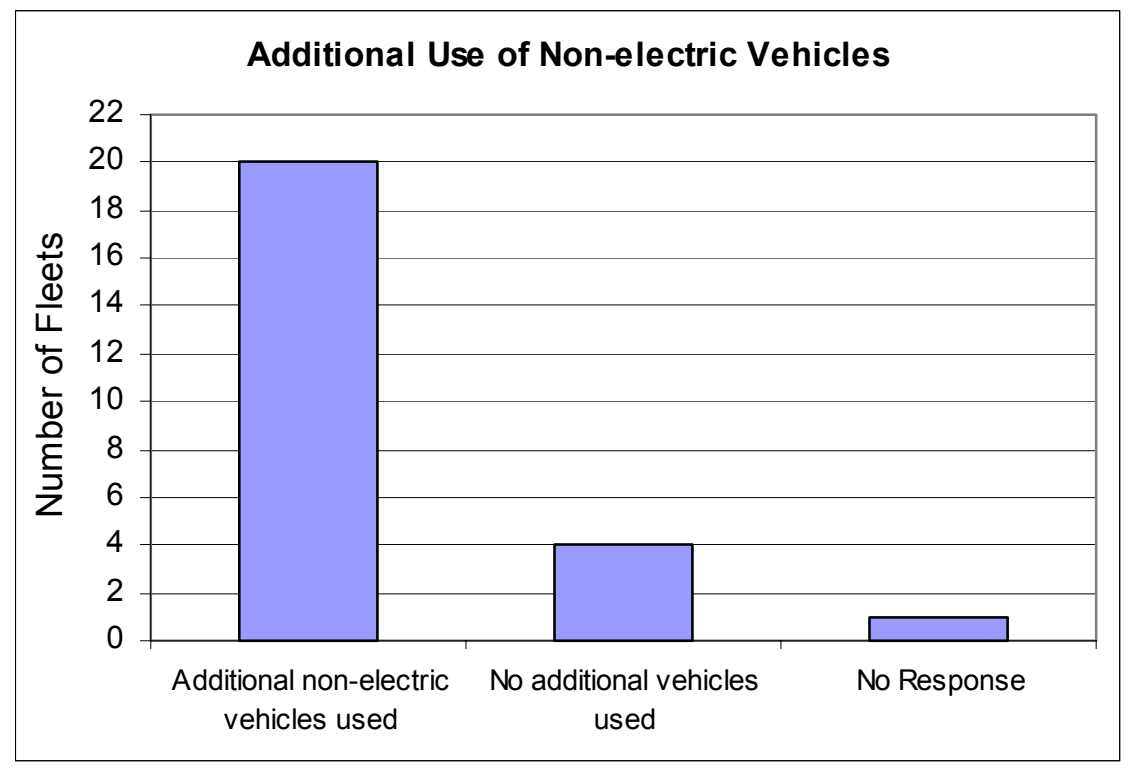

Figure 8. Number of fleets that used vehicles other than their electric vehicles to accomplish a mission.

The following comments were received as reasons for using a nonelectric vehicle to accomplish a mission:

- Destination out of electric vehicle range (14 fleets) 
- $\quad$ Could not depend on the electric vehicle (2 fleets)

- $\quad$ Electric vehicle was being repaired (4 fleets)

- Electric vehicle was not available (2 fleets)

- $\quad$ Right-hand drive needed for some Postal Service delivery points for curb line delivery (1 fleet)

- Payload limitation (1 fleet)

- No charging station at destination (1 fleet).

The vehicles used in place of the electric vehicles also varied in model. One fleet reported the use of a natural gas vehicle. The remaining replacement vehicles are assumed to be gasoline vehicles. The following list of vehicles were used in place of the electric vehicles:

- $\quad$ Gas truck (14 fleets)

- $\quad$ Natural gas vehicles (1 fleet)

- $\quad$ Varied (2 fleets)

- Conventional vehicle (1 fleet)

- $\quad$ Right-hand drive postal vehicle (1 fleet).

\subsection{Vehicle Performance}

When asked, 24 of 25 fleets reported that the electric vehicles were easy to operate (Figure 9).

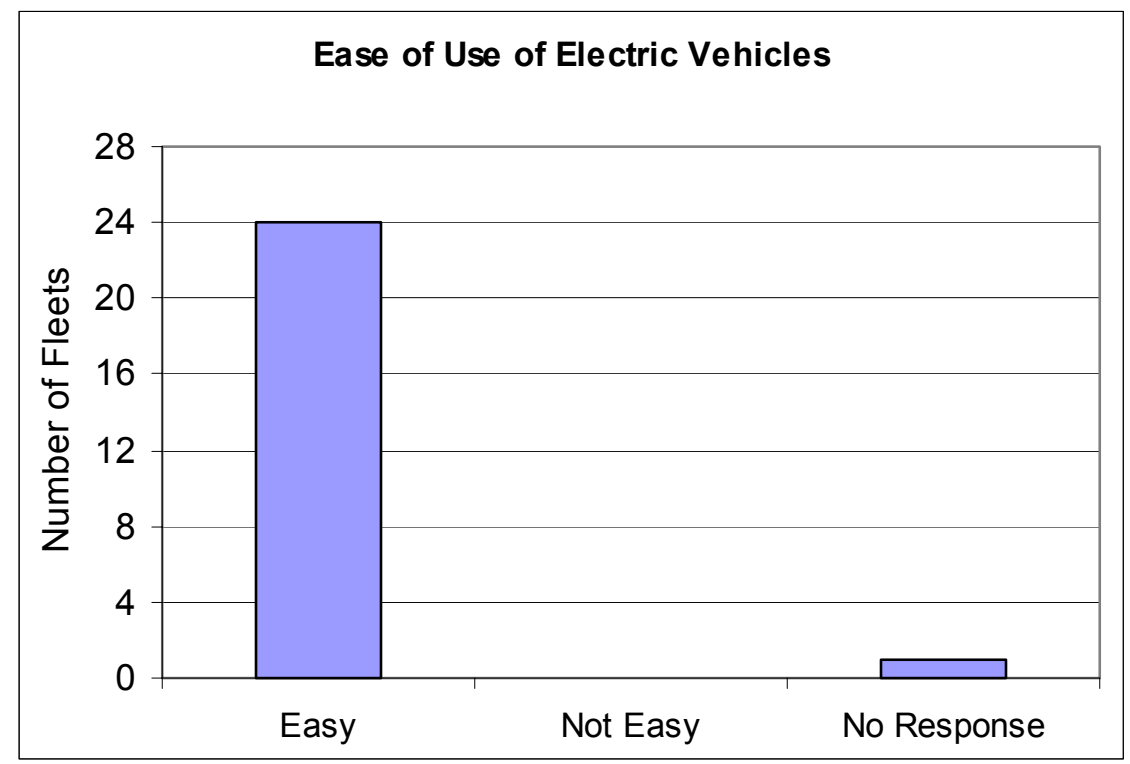

Figure 9. Number of fleets that indicated electric vehicles were easy or not easy to operate.

The fleets were asked if they thought their electric vehicle(s) could carry adequate payload. Twentytwo of 24 fleets believed that their electric vehicles could carry adequate payloads for the missions they were assigned (Figure 10). 


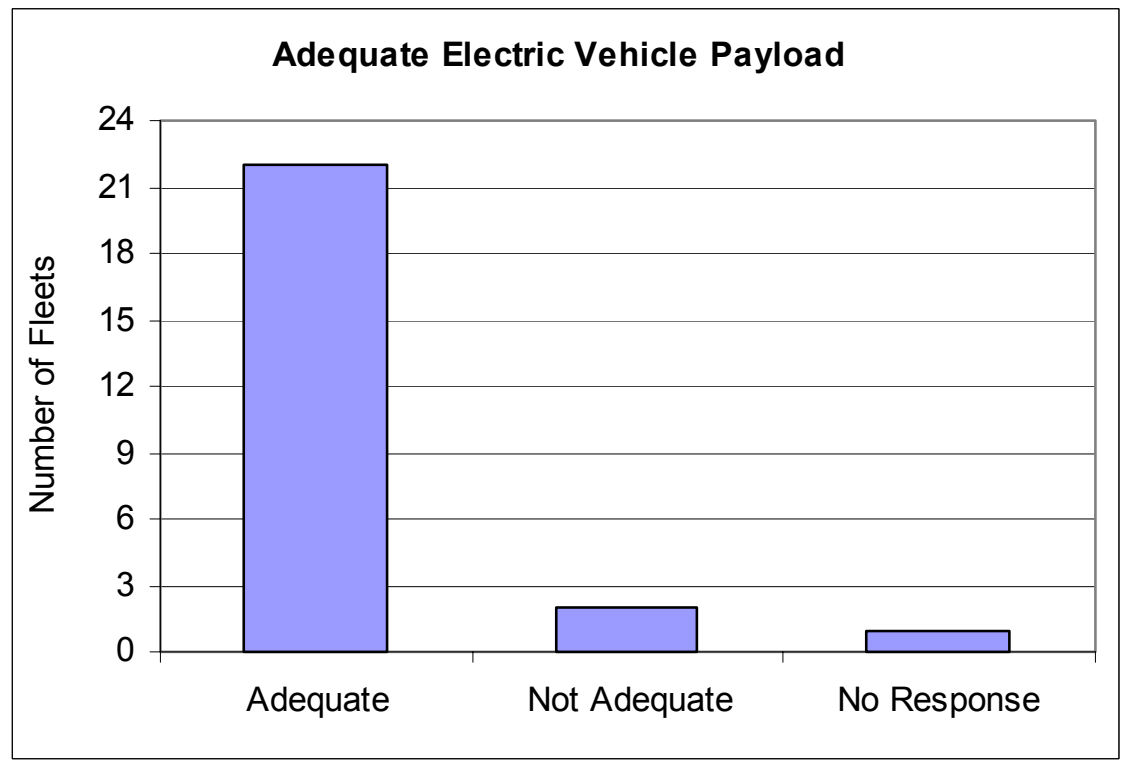

Figure 10. Number of fleets that indicated their electric vehicles could carry adequate payloads.

The fleets were asked if their electric vehicles had sufficient range. Fourteen of 22 fleets indicated that their electric vehicles had insufficient range (Figure 11).

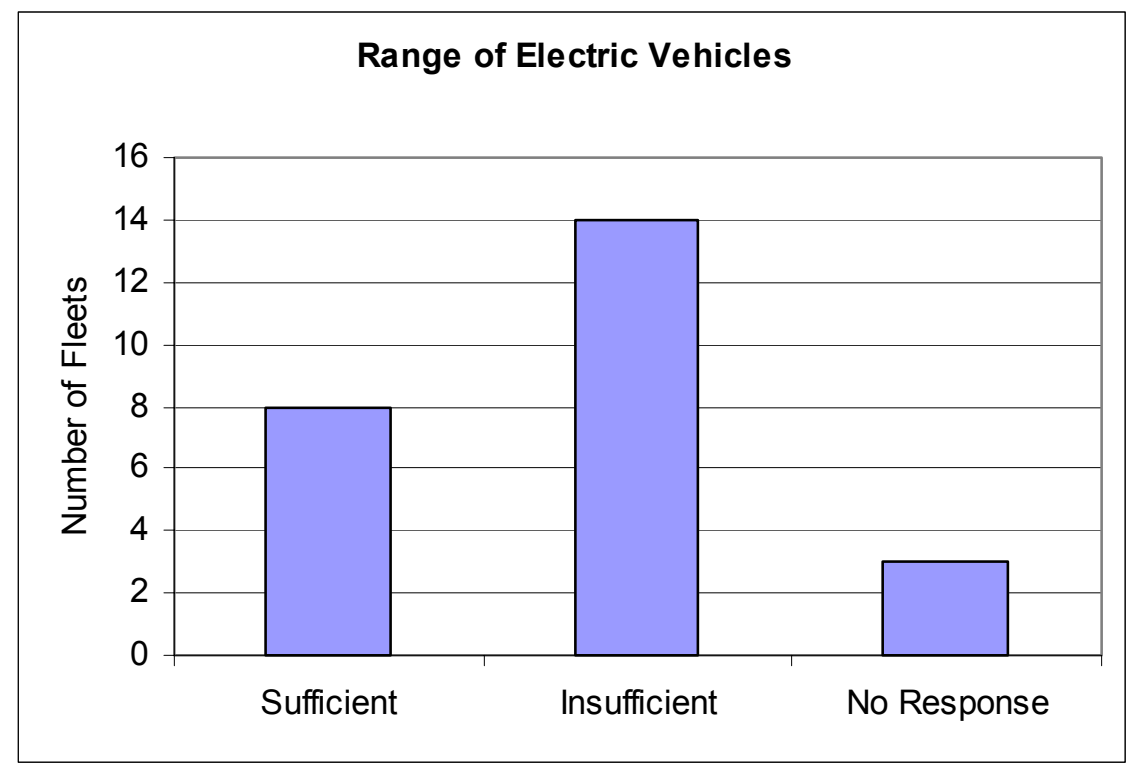

Figure 11. Number of fleets that indicated if the range of their electric vehicles was adequate.

The electric vehicles were used for a variety of different tasks. Following is a list of the tasks that the electric vehicles were used for by 23 of the fleets. Some fleets listed more than one task:

- Daily travel around complex (6 fleets)

- Various tasks (1 fleet)

- $\quad$ Administrative runs (3 fleets) 
- $\quad$ Transport equipment (3 fleets)

- Mailroom vehicle delivered and picked up mail on a set route everyday (5 fleets)

- Maintenance, operations, and facilities support (4 fleets)

- Transport personnel (6 fleets).

\subsection{Problems Encountered}

Twenty-two of 25 fleets reported having problems with their electric vehicles (Figure 12). The problems reported by the 22 fleets were grouped together (Sections 5.4.1 to 5.4.5) and include:

- Mechanical problems

- Traction battery problems

- Charging problems

- Driving problems

- Other problems.

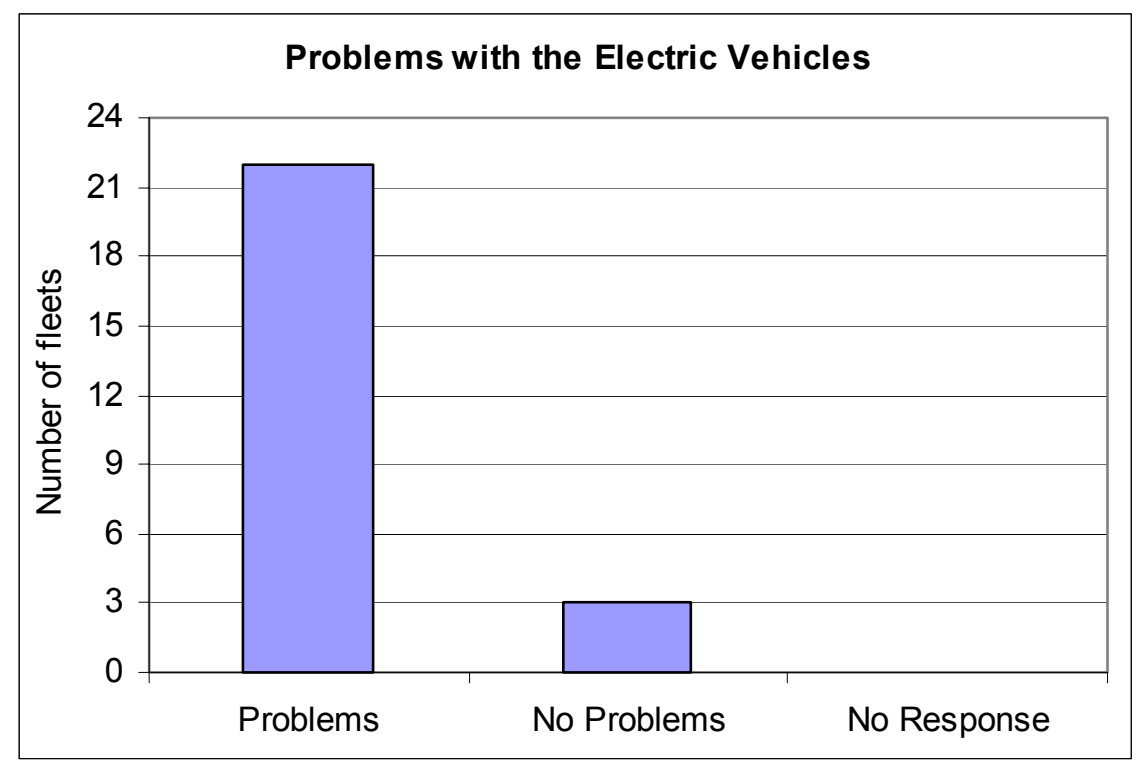

Figure 12. Number of fleets reporting problems with their electric vehicles.

\subsubsection{Mechanical Problems and Nonpropulsion Battery Problems}

The mechanical and nonpropulsion battery problems reported by the fleets are listed below. Unless stated otherwise, one fleet reported each problem:

- The wrench light on the dash came on numerous times (3 fleets)

- $\quad$ Power steering pump failures (3 fleets)

- Vehicle would not go into reverse

- Ongoing problems with air conditioner

- Brake problems

- Trans-axel failed 
- Auxiliary battery failed

- Horn failed

- $\quad$ DC/DC and AC/DC converters failed

- $\quad$ Circuit board failed (2 fleets)

- Replaced coolant pump

- Sensors

- Software

- Fuel door

- Air conditioning compressor

- Fan relay

- $\quad$ Fuse

- $\quad$ Steering rack

- Gearshift indicator indicated wrong gear.

\subsubsection{Traction Battery Problems}

Twelve of 21 fleets reported running out of battery charge while operating their electric vehicle(s) (Figure 13). It is unknown if the battery charge depletions were caused by unexpected decreases in vehicle range or drivers attempting to drive beyond the vehicles' known capabilities.

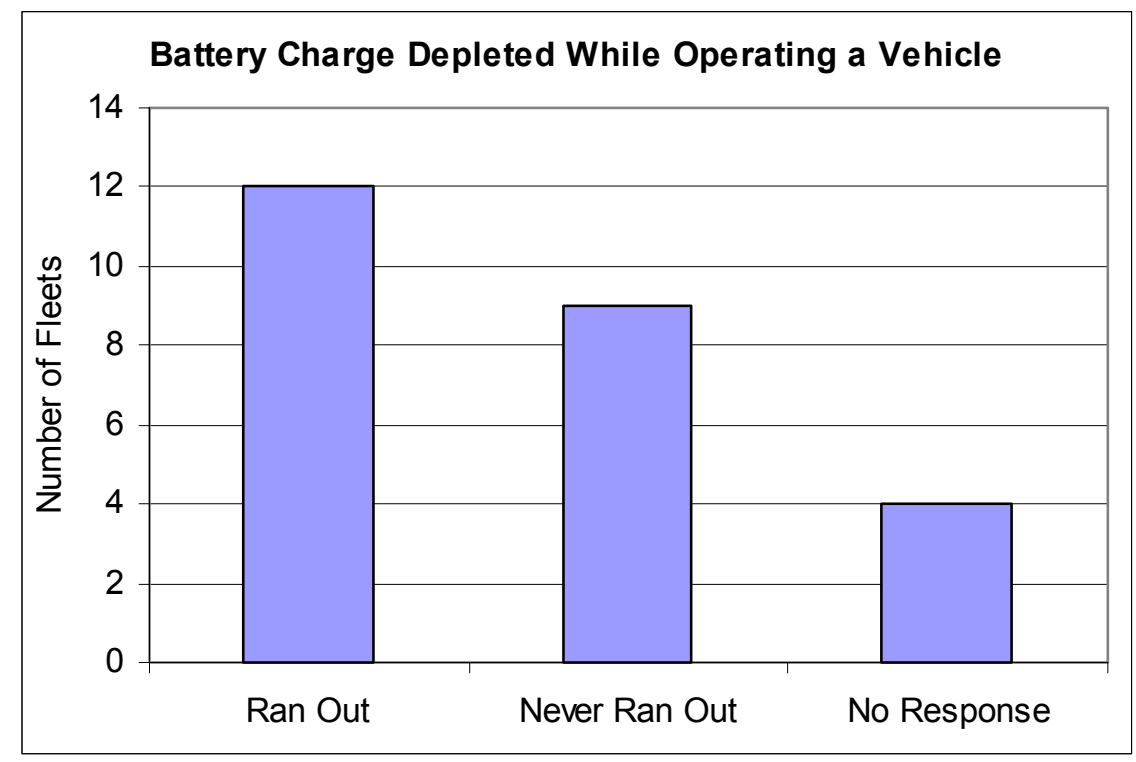

Figure 13. Number of fleets reporting if their electric vehicles ran out of battery charge while in use.

The specific battery problems reported by the fleets are listed below. Unless stated otherwise, one fleet reported each problem:

- $\quad$ Replaced 14 gel packs because of evaporation

- After driving about 30 miles, the vehicle went into the save energy mode and cut the power

- Batteries would not retain a charge (5 fleets)

- Battery charge suddenly dropped from half charge to no charge and instantly lost power 
- The batteries would not fully charge (7 fleets)

- $\quad$ Poor charging in cold weather

- Battery charge indicators

- $\quad$ Battery module

- Both the EPIC and Ranger had problems maintaining the charge in the 12-volt battery, unless driven daily [authors note: this does not appear to be a traction battery problem, but it was reported as such]

- $\quad$ The EPIC had a recurring problem with the battery pack overheating, which caused the vehicle to shut down while operating.

\subsubsection{Charging Problems}

Thirteen of 24 fleets reported having problems charging the electric vehicles (Figure 14).

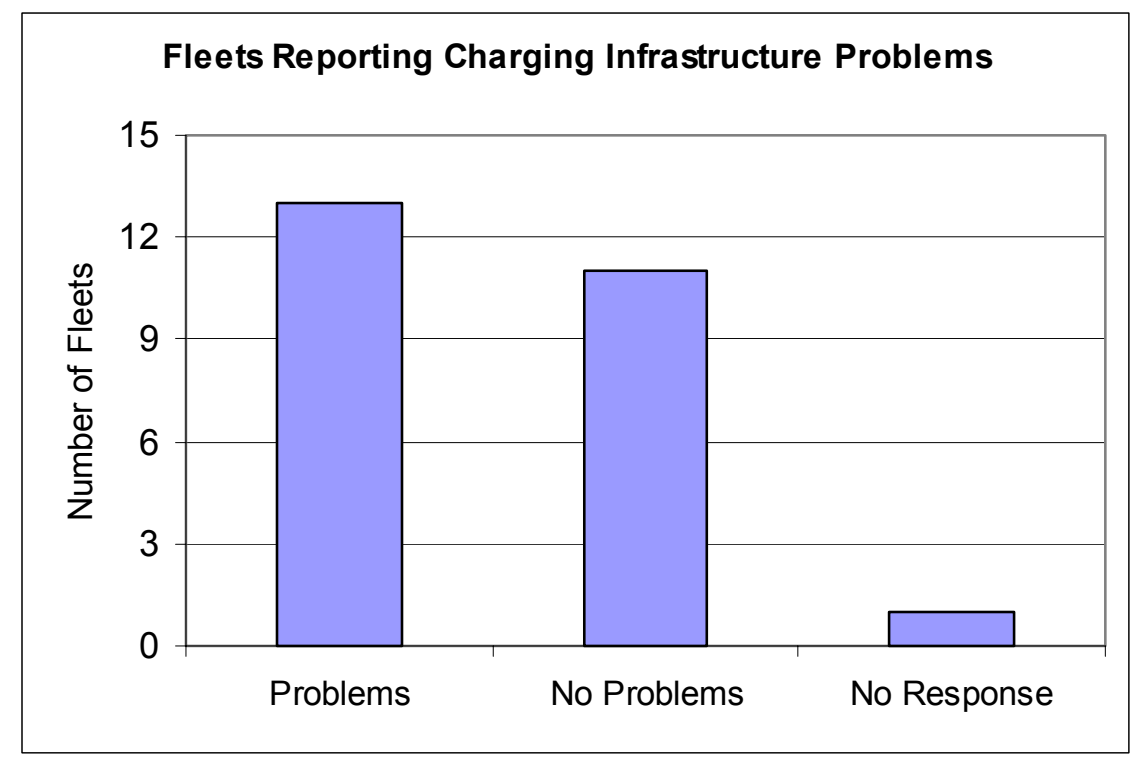

Figure 14. Number of fleets reporting problems with their charging infrastructure.

The charging problems reported by the fleets are listed below. Unless stated otherwise, one fleet reported each problem:

- $\quad$ Nonspecified problem with charger unit

- $\quad$ Replacement of charging unit plug (3 fleets)

- Went through several charging stations - seemed to be quite a problem for a while

- Charger would not work due to bad circuit card

- Charging receptacle (female port) on vehicle broke and was replaced (2 fleets)

- Malfunctioning of the charging station (5 fleets)

- $\quad$ Cracked plug on the vehicle end

- Charger had to be reset (6 fleets)

- Broken or detached charging cables

- Motherboard failure in charging unit (3 fleets) 
- $\quad$ Capacitor failed (3 fleets)

- Charging unit had problems delivering the charge (3 fleets)

- Difficulties installing the charging unit (2 fleets)

- Charger would not work properly

- Cable for the attachment was pulled out of the charger station

- Some vehicle users reported having to reset the charger frequently

- Charging unit was defective

- $\quad$ Electric vehicle would never take a full charge (2 fleets)

- The level of charge decreased dramatically during cold weather- "we had a charge of 50 in warm weather and a charge of 20 in cold weather" (3 fleets) [authors note: the meaning of this comment is assumed to be 50 miles in warm weather and 20 miles in cold weather]

- Vehicle would not take or maintain a charge at times (2 fleets).

\subsubsection{Driving Problems}

Nine of 23 fleets reported that their vehicle(s) broke down during use (Figure 15).

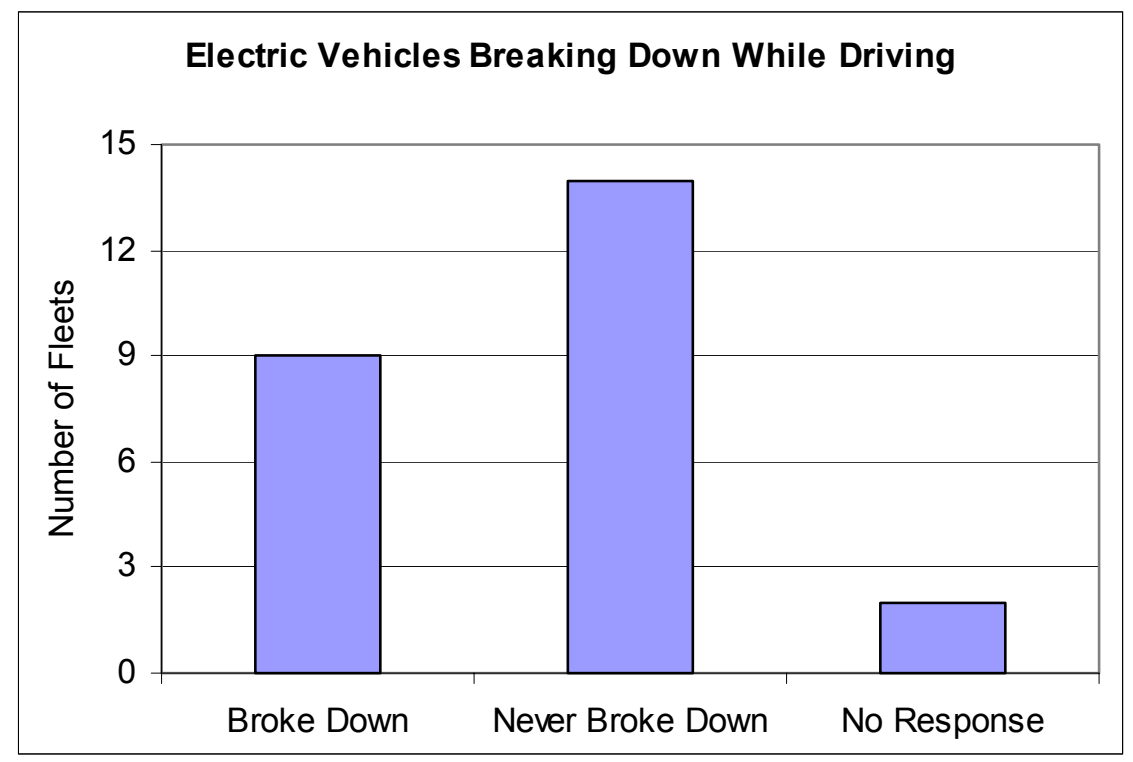

Figure 15. Number of fleets reporting that their electric vehicle(s) broke down while in use.

The fleets reported the following problems while driving the electric vehicles. Unless stated otherwise, one fleet reported each problem:

- Sometimes the vehicle(s) would not move, even when the battery was fully charged

- Normal flat tires

- Several times the vehicle's warning indicators came on while driving for one reason or another

- Some power failures resulted from battery module breakdowns or electronic component issues

- Lost power and the "wrench" light came on

- Battery light came on 
- Shorts in wiring harnesses on all 20 Ford Rangers disabled the vehicles

- The EPIC had a recurring problem with the battery pack overheating, which caused the vehicle to shut down while operating.

\subsubsection{Other Problems}

Below is a list of other problems that the fleets had with their electric vehicles. Unless denoted otherwise, one fleet reported each problem:

- As the vehicle aged, the range of the vehicle per charge got shorter (4 fleets)

- Occasionally, the vehicle was driven beyond their capable SOC (state of charge) range (2 fleets)

- Driver's seat belt would not retract

- Contract repairs were not performed in a timely manner.

\subsection{Maintenance}

This section covers the reported scheduled and unscheduled maintenance of the electric vehicles.

\subsubsection{Scheduled Maintenance}

The questionnaire asked what types of scheduled maintenance were required for the electric vehicles and if the fleets had to pay for any of this maintenance.

Seventeen of the 25 fleets indicated that all scheduled maintenance was performed by the manufacturers under warranty and there were no out-of-pocket expenses incurred by the fleets.

The responses for the remaining eight fleets were not clear. Generally, they indicated that they did not have scheduled maintenance performed, they performed their own scheduled maintenance, or the scheduled maintenance was taken care of by the Potomac Electric Power Company for GSA and some other fleets.

The fleets reported the following scheduled maintenance was conducted:

- Vehicles were serviced as needed - the only place to service an electrical vehicle is a 540 miles round trip

- Recalls from the factory that needed to be done

- The only scheduled maintenance performed on site was operator maintenance, i.e., tire, battery, fluid level checks, etc.

- Three thousand-mile checkup

- Update vehicle's software.

\subsubsection{Unscheduled Maintenance}

The following is a list of unscheduled maintenance reported by the fleets. Several of the reported maintenance needs are not electric vehicle specific. If the fleet reported any maintenance costs they were responsible for, the amount of the cost is in parenthesis:

- Replaced defective battery packs on all 14 vehicles

- Whenever the wrench light came on

- Vehicle experienced charging problems

- $\quad$ Replaced charger plug

- Charging problems 
- $\quad$ Power steering failed

- $\quad$ Battery pack problems

- $\quad$ Broken windshield

- One location, which had six of the Rangers, reported: "Batteries are no longer under warranty (\$5400 included the cost of batteries and labor)

- One location, which had seven of the Rangers, reported: "Repairs have been done on the battery packs and on the charging mechanisms" (\$2000.00 to \$5000.00)

- Faulty battery control module caused multiple batteries and high-voltage sense circuit failures

- Damaged charger inlet

- Recharge auxiliary battery and weak traction battery module

- $\quad$ PS motor controller shorted internally

- Loose HVPD box cover

- $\quad$ Failed contractor assembly and misrouted high-voltage wiring

- $\quad$ Replaced battery pack

- $\quad$ Repaired charger, replaced broken connector plug (\$1,697.50)

- Replaced broken charging receptacle

- $\quad$ Replaced the seatbelt, door latch, and two mail trays

- Repaired a key broken in the door

- Replaced the coolant pump, battery charge indicators, circuit boards, sensors, software, fuel door, battery module, air conditioning compressor, fan relay, fuse, and steering rack

- $\quad$ Battery failure, covered under warranty

- The following were reported by one fleet for one vehicle:

- $\quad 02 / 16 / 01$. "Check Engine" light came on and battery would not charge over $80 \%$-Dealer reprogrammed control module

- 09/12/01. Quit running after short time and would not always take a charge-Dealer Replaced Battery Pack and installed BCM software update

- 10/07/02. Lost Power Steering —Dealer replaced power steering pump and the AA module

- 10/24/02. Lost power, wrench light and battery light came on-dealer replaced BCM and IAM modules

- $\quad 01 / 03 / 03$. Gearshift indicator indicated wrong gear, driver seat belt would not retract, battery only charging $65 \%$-Dealer aligned gearshift, untwisted seatbelt, and replaced battery pack (according to work order)

- $\quad 01 / 28 / 03$. Battery would not hold charge, shift indicator and seatbelt problems - dealer rechecked battery and could not find problem; replaced shift indicator; could not duplicate seatbelt problem

- Vehicles had to be towed to a dealer at least 20 times during the lease

- $\quad$ Battery pack overheated (repeatedly); replaced 12-volt battery

- In the shop several times because the vehicle would not accept a charge

- $\quad$ Recall notices and battery recycling $(\$ 9,610.86)$. 


\subsection{Lease Status and Replacement Vehicles}

Based on the responses received for the 179 vehicles, $60 \%$ have been returned to the manufacturers. There will be 25 vehicles returned during the fourth quarter of 2003, and the 49 remaining vehicles will be returned during the first quarter of 2004.

\subsubsection{Lease Renewal}

In response to the question whether or not the fleets had tried to or were going to try to renew their leases, 17 fleets said no, six said yes, and two were unsure at the time. Of those that tried to renew their lease, 2 were successful (Figure 16).

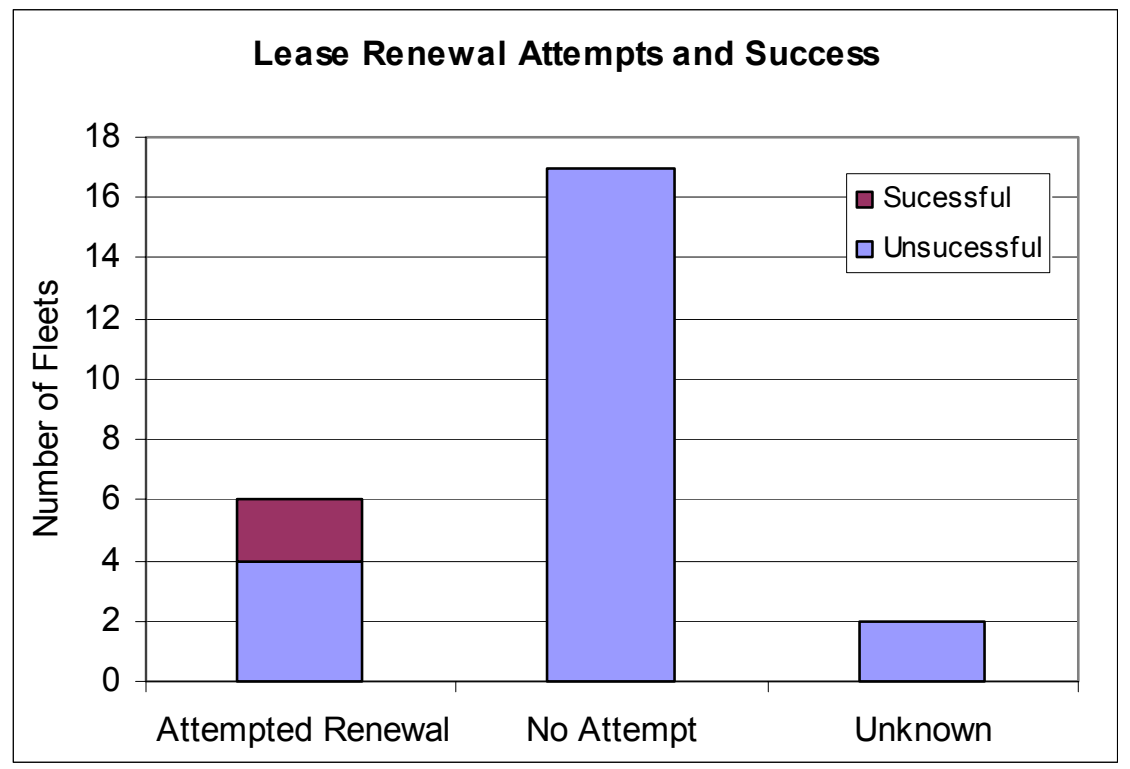

Figure 16. Number of fleets that tried to renew their electric vehicle leases, and the number of fleets that successfully renewed their leases.

The following comments were received from those fleets that tried to renew their leases. Unless denoted otherwise, one fleet reported each result:

- $\quad$ No success (2 fleets)

- Successful, unknown time

- Our organization was notified that we could not renew the lease

- Yes, however the vehicles have not been returned due to pending contractual issues; given 1 year, with 2 years optional

- No, because liability is too expensive to replace the battery packs and additional costs for component replacement from prorated leases; customers need bumper-to-bumper warranty for electric vehicles

- This was a nightmare. We started inquiring about renewing or extending the lease 1 year out. It sounded like there would be no problem, but in the end we received less than 2 weeks notice that the decision was not to renew. GSA and Ford offered very little help.

The following comments were received when the fleets were asked what reason the manufacturer or dealer gave for not renewing the lease: 
- We were so satisfied with the 14 electric vehicles that we extended the 3-year lease for another year. Ford legal people signed this 4th year extension and the USDA did also. Ford Motor Credit advised me after both parties had signed the 4th year lease that they would not repair any electric vehicle that went down because of a battery pack failure. Rather, they would remove the vehicle from our fleet. I said fine, but would Ford replace any and all vehicles that were removed from the lease with another electric vehicle or regular gas-powered pickup? They said they would get back to me on my request. The very next day, Ford Motor Credit repossessed the 14 vehicles. They served me with legal papers. Will NOT do business with Ford Motor Credit again. Ford yes, Ford Motor Credit, no

- The dealership would not allow me to renew the lease

- It was our decision not to renew the lease, not the dealers

- We have no desire to continue this lease. Not dependable

- I was told there were liability issues involved with renewing the lease of the vehicles

- $\quad$ Service was no longer available

- They are not staying in the electric vehicle business

- The lease was expired and we no longer want to extend

- Daimler Chrysler did not give us an option to renew

- GSA informed us we could not renew the lease, and they will not replace the vehicles

- $\quad$ Line management at Ford could not come up with a policy. Ford would not work with GSA. GSA would not work with Ford. Battery warranty may be a "show stopper."

- GSA vehicle leasing is not offering electric vehicles. Limited range greatly restricted vehicle assignments and use. Available recharging sites restricted vehicle assignments and use. Difficulty overcoming customer perception of electric vehicles

- $\quad$ GSA informed us that the lease would not be extended

- We, the consumer, do not want to renew the lease, because of the trouble of the vehicle holding its charge.

\subsubsection{Future Replacement Vehicles}

Ten of 21 fleets are planning on replacing their electric vehicles (Figure 17) with another vehicle type (Table 6), ten will not replace the electric vehicles, and 1 fleet is unsure. 


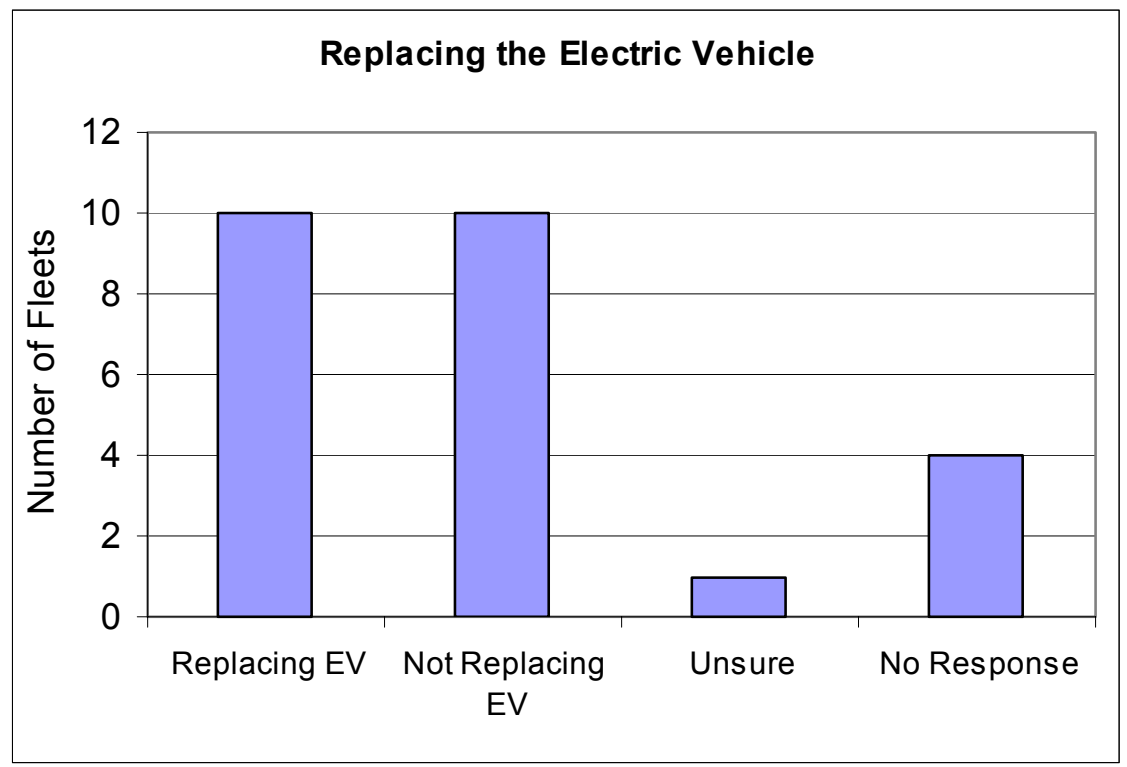

Figure 17. Number of fleets indicating they plan on replacing their electric vehicles at the end of their leases.

Table 6. Replacement vehicles, listed by vehicle year, make, model, and fuel type, with which ten fleets have replaced or with which they will replace their electric vehicles.

\begin{tabular}{|c|c|c|c|c|}
\hline Fleet & Year & Make & Model & Fuel-type \\
\hline 1 & 2003 & John Deere & Worksite Gator & Diesel \\
\hline 2 & 1995 & Ford & Aerostar & Gasoline \\
\hline 3 & Current model & Any make & Light pickup & $\mathrm{CNG}$ \\
\hline 4 & 2003 & Honda & Civic & Hybrid \\
\hline 5 & & $\begin{array}{l}\text { GSA Vehicle } \\
\text { e.g., sedan, truck, van, etc. }\end{array}$ & & $\begin{array}{l}\text { Gasoline } \\
\text { CNG or E85 }\end{array}$ \\
\hline 6 & 2000 & Ford carrier route vehicle & USPS special model & Gasoline \\
\hline 7 & 2000 to 2002 & Ford and Chevy & Compact pickups, sedans & $3 \mathrm{CNG}, 12$ gasoline \\
\hline 8 & 2003 & & Minivan & Flex fuel \\
\hline 9 & & Any make & & E85 or $\mathrm{CNG}$ \\
\hline 10 & & Unknown at this time & & \\
\hline
\end{tabular}

\subsection{User Comments}

This section presents the comments received from the fleets.

\subsubsection{Leasing Another Electric Vehicle}

The fleets were asked if they would lease another electric vehicle to replace the one(s) they had. Nine of 22 fleets responding said that they would replace their current electric vehicle(s) with another electric vehicle, if possible. The following comments were received about leasing another electric vehicle: 
- The vehicle was nice to operate in the tunnels because of it being quiet and no fuel fumes. The problems that we had with the wrench light outweighed the benefits

- Advancement in the technology and funding would play a major role in leasing another vehicle

- Only if Ford pays to have vehicles hauled and delivered whenever service is required and only if charging stations are supplied at no charge

- Just not enough passenger room

- They are perfect vehicles for this small installation

- Yes, if the lease was low cost

- Maybe if the range is longer

- Yes, depending on the cost, availability, and accessibility to service, and assuming that a similar warranty is available. At present, the nearest qualified Ford electric vehicle dealer is 180 miles away, which causes additional lost time because the unit must be transported to and from the dealer

- If the cost were reasonable and the technology improved, yes. We are not sure if the nickel metal hydride is the best option

- Too many problems with charging.

\subsubsection{Expanding the Use of Electric Vehicles}

The fleets were asked if they would expand their use of electric vehicle(s) if additional vehicles were available; eleven responded yes, fourteen responded no. Following is a list of comments received:

- If Ford solved the problems and if the range were expanded to around 100 miles

- Possibly, if they were more dependable

- Expansion must be aligned with our organization's objectives

- Not until there is a closer dealership to service the electric vehicles

- Maybe, if greater distance could be traveled with more passengers. Remember you just can't pull into a gas station or charging station and pull out a couple of minutes later

- This site is moving to using more E-85 powered vehicles in our fleet, and we anticipate having the infrastructure in place within the year

- If the mileage per charge were increased

- Use at plant sites

- $\quad$ Yes, these vehicles are a "perfect match" for U.S. Postal Service use

- Yes, depending on types/styles available, cost, accessibility to service, and warranty. The warranty is important because of the cost risk associated with battery failure

- If the cost was reasonable and the technology improved, yes. We are not sure if the nickel metal hydride is the best option

- Possibly in the future if "bugs" are worked out

\subsubsection{Feelings about Electric Vehicles}

The fleets were asked if they were happy with their electric vehicle(s); 19 fleets responded yes; 6 fleets responded no. The following comments were received:

- When it ran trouble free, we were happy. When the wrench came on, it cost us time and money to haul the truck to the nearest dealer, which was about 100 miles away, and they had the vehicle for an extended length of time. This is when we forgot about being happy about the vehicle. It is 
understandable that vehicles need repairing, but as little as we used the truck and as much time as it was in the shop for apparently the same problem, it was crazy

- $\quad$ Fine for travel within the park to supervise projects

- As long as we were able to keep them operating

- Initially, the users were very satisfied with the performance. However, as time went by, significant charges were incurred by the organizations that have these vehicles. One example is that the battery packs are no longer under warranty. A couple of our organizations have reported that they have had to pay upward of $\$ 4,800.00$ for new battery packs. Finally, the regional Ford dealership who provided these 19 vehicles is located over 100 miles away (a 2-hour drive) from the Laboratory. When we had problems with the vehicles, they had to be towed in, and often the organization was without their vehicle for several weeks. One organization reported: "per my conversation with Louie at (specific Ford dealer) on 04-14-03, the truck has not been worked on to date, but will be checked out on $04-14-03$. The price could be zero, or up to $\$ 4,800.00$ if the battery pack needs replacing"

- The electric vehicles require less maintenance than gasoline-powered vehicles

- $\quad$ Range issues are the biggest problem

- Yes, very happy

- As indicated above, the function to which this unit was assigned was ideal for an electric vehicle. It involved light loads for short trips, within a small operating radius. Plus, the vehicle routinely returned to the charging station location during the day, so the charge could be "topped off"

- The leased electric vehicles did help us meet the Executive Order (Greening the Government), DOE Alternative Vehicle Usage requirements, and the Federally mandated fuel reduction of Government Fleets

- Vehicle will not accept or maintain a charge. When the vehicle was out of service, it was gone at least one week and frequently more than that. The vehicle is used daily, so it is hard to have it gone so much. Dealer had one mechanic who could work on it

- With reservations!

- Until we started having problems

- The battery charge is very unreliable. We never know if we can make it back to the charging station. It will sometimes show a good charge then drop suddenly. At present we are getting only about 12 miles between full charge and depletion.

\subsubsection{Recommending Electric Vehicles to Others}

The fleets were asked if they would recommend electric vehicle(s) to others; 16 fleets responded yes; 9 fleets responded no. The following comments were received from the fleets regarding recommending electric vehicles to others:

- $\quad$ They would be very handy for short trips

- They may work well for others

- Great for air quality control

- Only for short trips

- Only if they were keeping it close to a charging station. Around town or somewhere that they could reach that had a charging station

- It depends. The terrain in Los Alamos: canyons, mesa tops, and remote mountainous sites limited our options as to where we could place the electric Rangers 
- I would recommend them only to organizations whose driving requirements are short trips

- Myself, I enjoyed driving the Ford Ranger

- Yes for certain limited applications, and especially if the cost was more along the lines of standard vehicles. Such a vehicle is ideal for use when trips are within a small travel radius and especially if/when trips often end at the charging station location so the charge can be "topped off"

- They are the most environmentally friendly option

- Depending on range and frequency requirements

- The service from the batteries is not sufficient.

\subsubsection{Satisfaction Scale}

The fleets were asked on a scale of 1 to 5 , if they were satisfied with the performance of their electric vehicle(s). The majority of the fleets replied that they were satisfied to extremely satisfied (Figure 18).

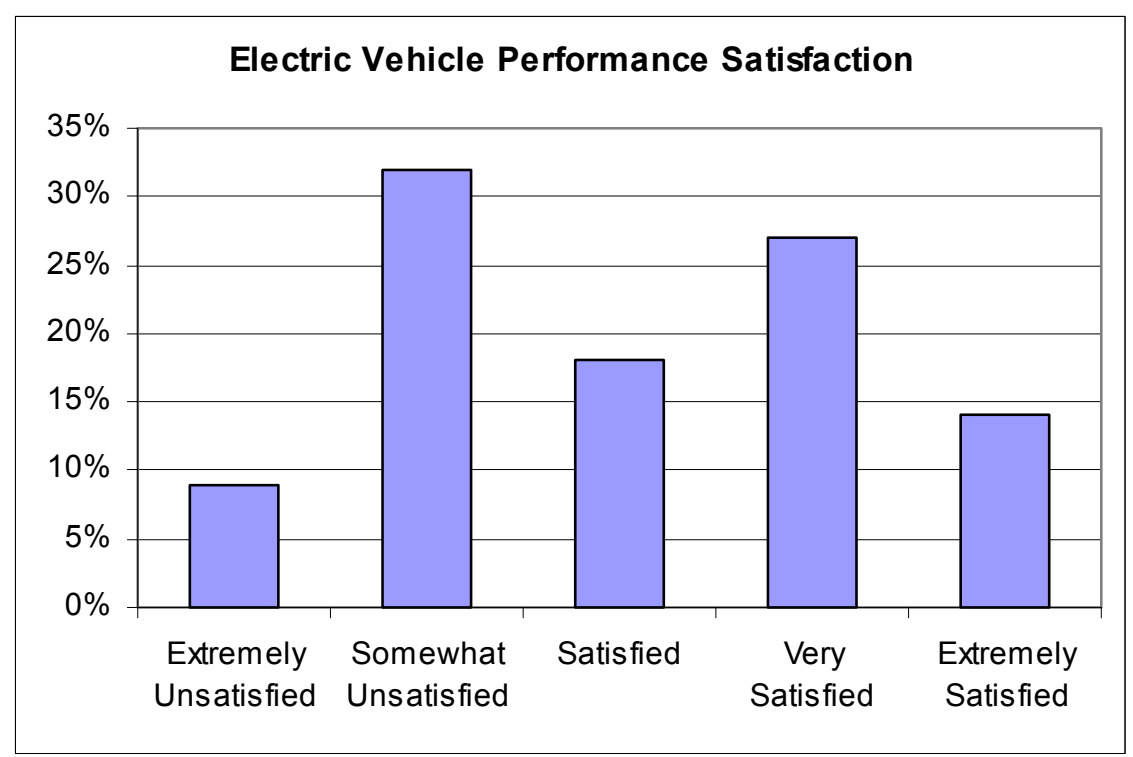

Figure 18. Fleets reporting overall satisfaction or lack of satisfaction of electric vehicle performance.

\subsubsection{Additional Comments}

The following additional comments were received from the fleets regarding their electric vehicles:

- My main complaint is that there were no service facilities in the local area. The truck would have to be transported over 130 miles one way to be serviced. The problem was that when it was repaired we had to go get it on a trailer and bring it back to Vancouver. The service situations were terrible

- Generally pleased, but a conventional vehicle was required for trips of any distance

- Poor performance in wintertime due to charging capabilities

- Always place the charging station where it will receive direct sunlight during winter months

- Generally, some organizations had good luck with their vehicles. A couple of organizations seemed to have more problems with their vehicles. Finally, in reviewing the records that (specific Ford dealer) provided to us, we noticed that on a couple of occasions, the dealership reported (the) "driver 
not allowing enough time to recharge during cold weather conditions. See owner's manual for details"

- Ford Motor Company covered all warranty and recall costs

- The response from the Ford dealership on charger repair or replacement was not adequate. The dealership had a backlog of electric vehicles in for repair causing a poor turn around time, at times upward of 4 weeks

- The Chrysler EPICs were used for daily mail delivery. They replaced previous gasoline vehicles with no changes in delivery operation. The EPICs performed this task as well as their gasoline counterparts. Additionally, driver comfort was improved due to no hot engine idling while operating the vehicle in the slow, stop-and-go driving pattern of these mail delivery vehicles. They were costeffective, and virtually maintenance-free. With proper charging management, and adequate battery pack replacement, they probably would have lasted for 200,000 miles without re-powering

- The opportunities to use and demonstrate electric vehicle technology is extremely rewarding and has helped us not only do our daily tasks, but to demonstrate an alternative to petroleum fuel energy in the process. The electric vehicle was displayed at several events, such as Earth Day, where it received considerable attention. It was especially nice to show future generations the technology and get them started thinking about energy options. We are extremely grateful to have the opportunity to use and demonstrate the electric vehicle

- Lawrence Berkeley Laboratory has made every effort to reduce dependency on unleaded fuel. All of our light vehicle replacements are for alternative fuel vehicles whenever possible. It would be helpful to know that the agencies supplying vehicles to the government did a better job promoting and providing alternative fuel vehicles, including electric

- These were a good novelty item for selective use. I would be willing to try electric vehicles again in the future, when technology improves the range and recharge time, especially the range!

\section{PETROLEUM DISPLACEMENT AND EMISSIONS REDUCTIONS}

In order to calculate the petroleum displaced (amount of gasoline consumption avoided), the Environmental Protection Agency's Fuel Economy Guide for model year 2000 was used (http://www.fueleconomy.gov/feg/FEG2000.htm). An average fuel economy of $18 \mathrm{mpg}$ is assumed for calculating the petroleum displaced by the electric vehicles. The 18-mpg figure is based on vehicles equipped with 6-cylinder gasoline engines used in city driving, which is most typical for electric vehicle use. Therefore, based on the 700,545 estimated annual miles driven for the 220 vehicles, the estimated annual petroleum displaced would be 38,919 gallons of gasoline.

Definitively determining the air pollution benefits for the 220 electric vehicles is more difficult than determining the petroleum displacement benefits, because the emissions data for the older vehicles that the electric vehicles replaced is impossible to obtain, and the actual emissions on a per-vehicle basis depends on how well the vehicle is maintained and how it is driven. However, some very conservative assumptions allow for calculating the pounds of smog-forming emissions avoided by using the 220 electric vehicles. Data for currently available vehicles is again used, knowing that such technological advancements as catalytic converters, exhaust gas re-circulation, and electronic fuel controls have made today's vehicles cleaner than the vehicles replaced by the EPICs and Rangers. According to the EPA Green Vehicle Guide (http://www.epa.gov/greenvehicles/), today's minivans and pickups (similar to the EPIC and Ranger) emit about 31 pounds of smog-forming pollution per 15,000 miles. Given the 700,545 estimated annual miles driven by the 220 electric vehicles, their use reduced emissions at least 1,448 pounds annually. 


\section{CONCLUSIONS}

- As evidenced by the fleet responses, the electric Rangers and EPICs were well liked, even though the Federal fleets had many problems operating the vehicles. The problems were likely caused by many factors, including actual physical problems with the vehicles and the charging infrastructures.

However, other factors such as how the vehicles were operated, unrealistic or uninformed expectations, poor mission placements, and minimal training may have contributed to problems with the vehicles.

- The Federal fleets often did not receive sufficient training to understand how the electric vehicles differed from other vehicles. Electric vehicles will not operate when the batteries are "empty" just like a gasoline vehicle will not operate with an empty gasoline tank. Electric vehicles also require maintenance support like gasoline vehicles do, but this is often overlooked. It is accepted practice that fluid levels such as motor oil and radiator coolant must be periodically checked in a gasoline vehicle and the oil should be changed every 3,000 miles, while there appears to be a mindset that electric vehicles only have to be plugged in. Adequate maintenance must also be performed on electric vehicles on a regular basis for successful use. Based on some comments, the electric vehicles were sometimes located hundreds of miles from a service facility, which insures failure.

- The comments listed in the Recommending Electric Vehicles to Others section clearly indicate that the Federal fleets would recommend the electric vehicles to others, if the vehicles were placed in missions where distances matched the vehicles' capabilities. This is also true of gasoline vehicles, as small compacts are not expected to meet the demands of 8 or 10 passenger vans. Again, education must be adequate and expectations must be realistic to successfully place the electric vehicles. Electric vehicles will never replace all internal combustion vehicles in Federal fleets, but as seen at Luke Air Force Base, for instance, they can replace many of the vehicles when mission requirements and capabilities match. Luke is successfully using about 400 small electric vehicles in place of gasoline vehicles and reaping the benefits of petroleum reduction and reduced emissions.

- If full-size electric vehicles are again made available to Federal fleets, it is imperative that mission and vehicle capabilities be matched.

- There are many ways to judge the success or failure of the Incremental Funding Project:

- From a regulatory point of view, the Advanced Vehicle Testing Activity fully met the goal of supporting the deployment of electric vehicles in Federal fleets as required by Executive Order 13031. All available resources (funding) were used in a manner that maximized the number of vehicles deployed. Paying only half the incremental cost was enough of an incentive to the Federal fleets that all of the funding was used. If DOE had paid the full incremental costs, only one-half the number of vehicles (110) would have been deployed.

- Given that approximately 1,000 Federal employees were able to extensively operate the electric vehicles, the objective of increasing the awareness of electric vehicles by Federal fleets was achieved.

- Some supporters of the Incremental Funding Project thought this activity would "kick-start" the electric vehicle market. However, this was an unreasonable expectation, given that the 220 vehicles only equates to approximately $0.001 \%$ of annual automotive sales in the United States. Therefore, the success of this expectation will not even be addressed.

- Given the comments from some fleets regarding the distances some of the vehicles were from servicing centers, the vehicles should not have been located in remote locations. However, such a decision to the Federal fleets would have been difficult to enforce.

- Based on the responses to the questionnaire, the following overall conclusions can be reached: 
- The fleets felt that the plugs used to connect the vehicles to the charging infrastructure was easy to use (Figure 2) though most fleets had problems with the charging infrastructure (Figure 14).

- The vehicles were easy to use (Figure 9) and had adequate payload (Figure 10).

- The vehicle range was insufficient (Figure 11), with most fleets reporting problems with the vehicles (Figure 12) even though the vehicle problems generally did not include on-road failures (Figure 15).

- While most of the fleets did not attempt to renew their vehicle leases (Figure 16), it is not known if this was driven solely by dissatisfaction with the vehicles or prior knowledge that the manufacturers would not renew the leases.

- While clearly acknowledging with their comments that there were problems with the vehicles, $65 \%$ of the fleets responded positively when asked if they would recommend electric vehicles to others and $59 \%$ of the fleets were at least satisfied with the vehicles (Figure 18).

- Given that most of the 220 vehicles were/are being driven for a period of three years, the total petroleum-free miles driven will be approximately 2.1 million miles and the avoided gasoline use will total approximately 100,000 gallons for three years. In addition, based on an average of 4 trips per day (Figure 6), the Federal drivers made approximately one-quarter of a million petroleum-free trips each year in the 220 vehicles, avoiding a significant number of gasoline vehicle cold-starts. 


\section{APPENDIX A - DATA COLLECTION FORM}

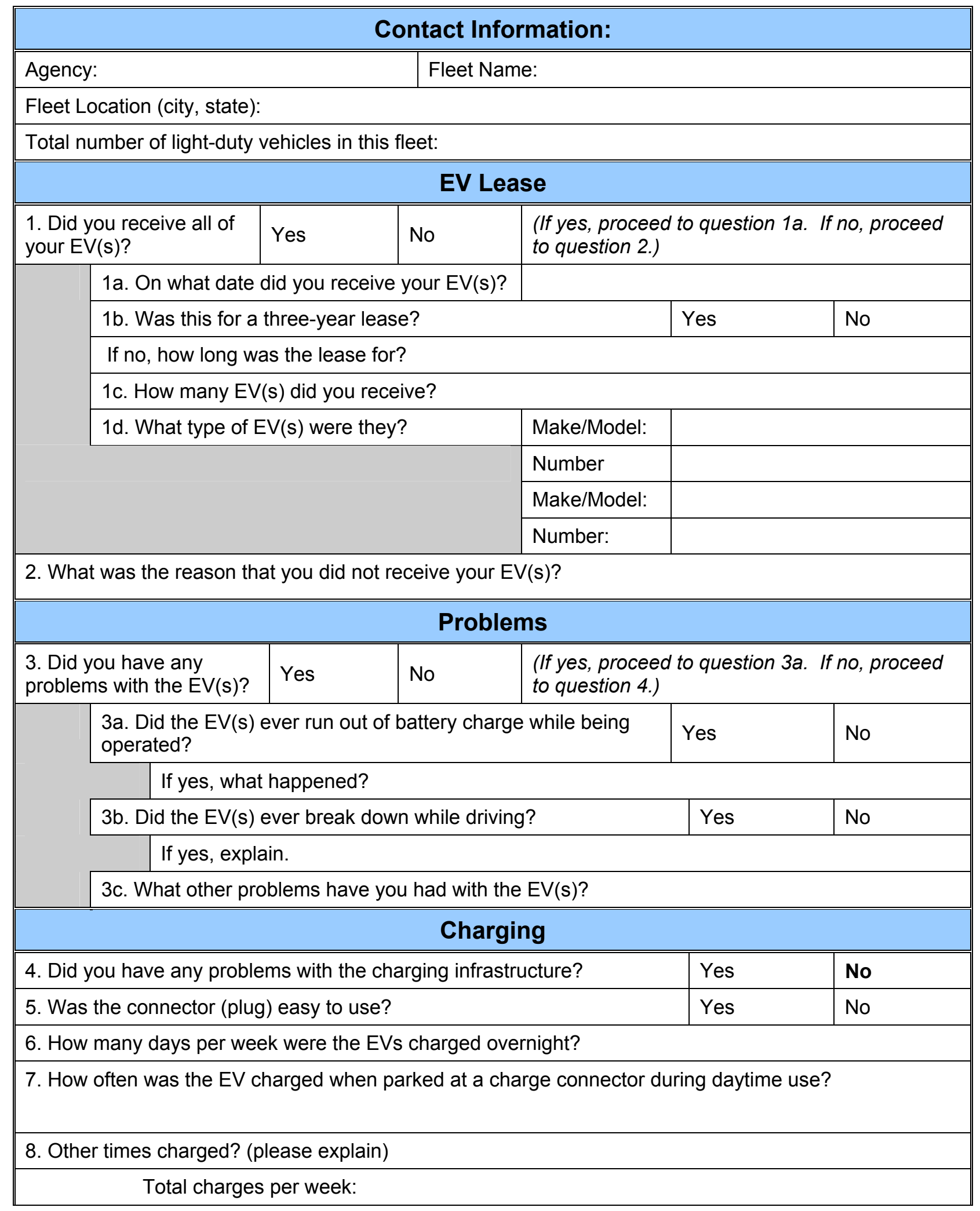


9. How many hours did the EV take to charge completely and from what state-ofcharge (SOC) was this from?

( $100 \%$ SOC - considered a full charge, $20 \%$ SOC nearly empty charge)

10. On average, when operating the EV, how low a level would the SOC reach before being recharged?

( $100 \%$ SOC - considered a full charge, $20 \%$ SOC nearly empty charge)

11. What was the maximum distance the $\mathrm{EV}$ would be driven before it was felt that the EV "had to be recharged"? (We are trying to measure the miles a driver would operate an EV before they felt that they had to recharge the EV.)

12. Did you have any problems charging the EV(s)? Yes No

\section{EV Lease Status and Replacement Vehicles}

\begin{tabular}{|l|l}
\hline \hline 13. Have you turned the EV(s) back in? & Yes
\end{tabular}

13a. If yes, on what date did you turn the $\mathrm{EV}$ (s) back in?

13b. If no, what date are you supposed to turn the EV(s) back in?

14. Did you / are you going to try to renew the lease?

14a. If yes, did you have any success renewing the lease?

$14 \mathrm{~b}$. If yes, how long is the new lease for?

14c. If no, what reason was given by the manufacturer/dealer for not renewing the lease?

15. If you could not renew the lease, will the EV(s) be replaced with another type of vehicle?

15a. If yes, what type?

\begin{tabular}{|l|l|}
\hline Make: & \\
\hline Model: & \\
\hline Year: & \\
\hline Fuel Type: & \\
\hline
\end{tabular}

\section{Maintenance}

16. What types of scheduled maintenance was required

16a. If you had to pay for the scheduled maintenance, please describe and provide the cost:

Maintenance event:

$\$$

17. What types of unscheduled maintenance was required?

17a. If you had to pay for the unscheduled maintenance, please describe and provide the cost: Maintenance event:

$\$$

\section{EV Use}

18. Was each EV assigned to a single driver or multiple drivers?

19. What was the total mileage that you put on each $E V$ ? 
19a. How many days per week did you use the $\mathrm{EV}(\mathrm{s})$ ?

19b. How many trips per day did you use the EV(s)?

19c. On average, how many miles did you drive the $\mathrm{EV}(\mathrm{s})$ each day or week?

20. What is the average distance the $\mathrm{EV}(\mathrm{s})$ were driven each day without being recharged?

21. Were any trips taken in another vehicle instead of the EV?

Yes

No

21a. If yes, why wasn't the EV used? (Please explain)

$21 \mathrm{~b}$. What type of vehicle was used instead of the EV?

\section{Performance of EV(s)}

22. Was the $E V(s)$ easy to operate?

\begin{tabular}{|l|l|} 
Yes & No
\end{tabular}

23. What was the primary EV mission (on average, what was it used for each day)?

24. Did the EV have adequate payload?

25. Did the EV(s) have enough range to fulfill its mission?

If no, please explain why not?

\section{Overall and Comments}

26. Would you lease another EV to replace the one you have?

27. Would you expand your use of EV(s) if they were available?

28. Would you recommend $\mathrm{EV}(\mathrm{s})$ to others?

29. On a scale of $1-5$, were you satisfied with the performance of your EV(s)?

30. Overall, were you happy with the $\mathrm{EV}(\mathrm{s})$ ?

\begin{tabular}{|l|}
\hline 1 \\
\hline Extremely \\
Unsatisfied
\end{tabular}

\begin{tabular}{|l|l}
\hline 2 \\
\hline $\begin{array}{l}\text { Somewhat } \\
\text { unsatisfied }\end{array}$
\end{tabular}

\begin{tabular}{|l|l}
\hline Yes & No \\
\hline Yes & No
\end{tabular}

31. Do you have any additional comments? 